$32=$

$6-2-63$

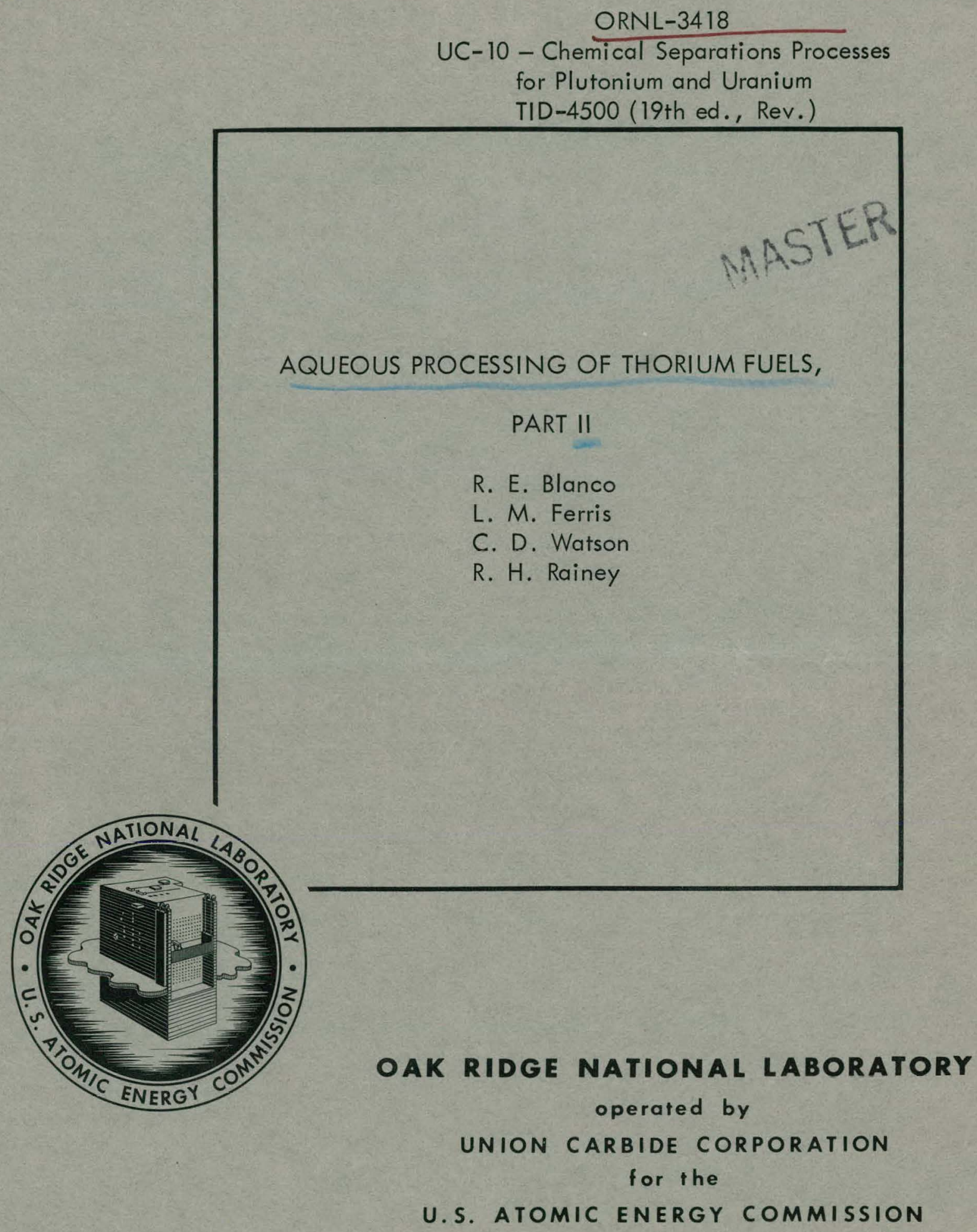




\section{DISCLAIMER}

This report was prepared as an account of work sponsored by an agency of the United States Government. Neither the United States Government nor any agency Thereof, nor any of their employees, makes any warranty, express or implied, or assumes any legal liability or responsibility for the accuracy, completeness, or usefulness of any information, apparatus, product, or process disclosed, or represents that its use would not infringe privately owned rights. Reference herein to any specific commercial product, process, or service by trade name, trademark, manufacturer, or otherwise does not necessarily constitute or imply its endorsement, recommendation, or favoring by the United States Government or any agency thereof. The views and opinions of authors expressed herein do not necessarily state or reflect those of the United States Government or any agency thereof. 


\section{DISCLAIMER}

Portions of this document may be illegible in electronic image products. Images are produced from the best available original document. 
Printed in USA. Price: $\$ 1.50$ Available from the Office of Technical Services

U. S. Department of Commerce Washington 25, D. C.

\section{LEGAL NOTICE}

This report was prepared as an account of Government sponsored work. Neither the United States, nor the Commission, nor any person acting on behalf of the Commission:

A. Makes any warranty or representation, expressed or implied, with respect to the accuracy, completeness, or usefulness of the information contained in this report, or that the use of any information, apparatus, method, or process disclosed in this report may not infringe privately owned rights; or

B. Assumes any liabilities with respect to the use of, or for damages resulting from the use of any information, apparatus, method, or process disclosed in this report.

As used in the above, "person acting on behalf of the Commission" includes any employee or contractor of the Commission, or employee of such contractor, to the extent that such employee or contractor of the Commission, or employee of such contractor prepares, disseminates, or provides access to, any information pursuant to his employment or contract with the Commission, or his employment with such contractor. 
ORNL -3418

Contract No. W-7405-eng-26

CHEMICAL TECHNOLOGY DIVISION

Chemical Development Section B

AQUEOUS PROCESSING OF THORIUM FUELS, PART II

R. E. Blanco, L. M. Ferris, C. D. Watson, R. H. Rainey

DATE ISSUED

JUN - 71963

OAK RIDGE NATIONAL LABORATORY

Oak Ridge, Tennessee operated by

UNION CARBIDE CORPORATION

for the

U. 5. ATOMIC ENERGY COMMISSION 


\section{THIS PAGE \\ WAS INTENTIONALLY \\ LEFT BLANK}




\section{CONTENTS}

Abstract

1. Introduction 2

2. Mechanical Processing 3

2.1 Mechanical Decladding of SRE Fuel 3

2.2 Shear-Leach 7

3. Aqueous Dissolution Methods 22

3.1 Ceramic Cores Clad in Stainless Steel, Aluminum, or Zirconium 22

3.2 Graphite-Base Fuel Elements 29

4. Solvent Extraction 35

4.1 Acid Thorex Process 35

4.2 Acid Interim 23 Process 37

4.3 Kilorod Program $\quad 37$

4.4 Protactinium Recovery Systems 40

5. Choice of Reprocessing Method 43

5.1 Thorium Fuel Processes 43

5.2 Processing Costs 45

$\begin{array}{ll}\text { 6. References } & 48\end{array}$ 


\title{
AQUEOUS PROCESSING OF THORIUM FUELS, PART II
}

\author{
R. E. Blanco, L. M. Ferris, C. D. Watson, R. H. Rainey
}

\section{ABSTRACT}

The status of aqueous processing methods for thorium fuels is reviewed. A specially designed 250-ton shear was successfully tested for shearing full-size simulated Consolidated Edison type unirradiated assemblies into 0.25-1.5 in. lengths. Pieces about 0.5-in. long are preferred since the core pellets are more severely crushed during the chopping operation, and consequently, the time to dissolve a core is minimized.

The Darex (dilute aqua regia) and Sulfex (4 to $6 \underline{M}$ sulfuric acid) processes for dissolution of stainless steel claddings were developed on a small scale with unirradiated fuel. In hot-cell tests on stainless-steel-clad $\mathrm{ThO}_{2}-\mathrm{UO}_{2}$ fuel pins irradiated up to 22,000 $\mathrm{Mwd} /$ ton of fuel, the core pellets were severely fractured, and losses of uranium and thorium to the Sulfex and Darex solutions were approximately 0.3 and $3-5 \%$, respectively. The latter losses are easily recovered in the extraction system.

Uranium and thorium can be recovered from graphite-base fuels by burning and dissolving the ash in nitric acid or by grinding to approximately 200 mesh followed by nitric acid leaching.

The Acid Thorex extraction process was developed to recover both uranium and thorium using tributyl phosphate (TBP) as the solvent and the Acid Interim 23 process to recover only the uranium using either TBP or di-sec-butyl phenyl phosphonate as the solvent. The "Acid" processes use nitric acid rather than aluminum as the salting agent. A cost estimate shows that in a plant optimized for the Acid Thorex process where both uranium and thorium are recovered, the overall processing cost $(\$ 8,400 /$ metric ton $T h)$ is only 
one third that $(\$ 26,000)$ for a plant optimized for the Acid Interim 23 process, where only the uranium is recovered. In the AEC conceptual plant the cost for Acid Thorex is only slightly lower $\$ \$ 26,000$ vs $\$ 24,900 /$ metric ton of $T h)$.

\section{INTRODUCTION}

Work is continuing at Oak Ridge National Laboratory to develop aqueous mcthods for processing thorium fuels. An extensive survey of ORNL work in this field (ORNL-32 19, Part I) was presented at the CNEN Symposium on Thorium Fuel Cycle at Rome in 1961. ${ }^{1}$ This survey included aqueous decladding methods, core dissolution and solvent extraction studies, corrosion data, and design criteria. The present paper (Part II) presents recent work on (1) mechanical decladding, shearing, and core-leaching procedures, (2) dissolution of graphite- and carbide-type fuels, (3) advanced solvent extraction methods, and, (4) for continuity, a brief review of previous work.

Objectives of the program are to develop more economical processing methods and to derive the data required to evaluate alternative recycle systems, for example, short-cooled processing (where protactinium is a problem) versus long-cooled processing (where protactinium has disappeared) and also recovery and reuse of thorium vs the exclusive use of fresh, unirradiated thorium in the fuel recycle system. Primary effort has been placed on stainless-steel-clad $\mathrm{ThO}_{2}-\mathrm{UO}_{2}$ fuels of the Consolidated Edison type (CETR) and graphite-bearing fuels similar to those proposed for the High Temperature Graphite (HTGR) and Pebble Bed Reactors, with a minor effort on aluminum-clad (Borax IV) or zirconium-clad fuels. The shear-leach (also called, "chop-leach") processing development work was carried out on an engineering scale with a 250-ton shear, using tubular stainless steel assemblies filled with $\mathrm{UO}_{2}, \mathrm{ThO}_{2}-\mathrm{UO}_{2}$, or ceramic cores to simulate actual fuel. SRE core 1 spent fuel was used in the mechanical decladding development program. Cladding 
dissolution studies with unirradiated $\mathrm{ThO}_{2}-\mathrm{UO}_{2}$ fuels were performed on an engineering scale, but the core dissolution and extraction studies were made only on a laboratory scale with small irradiated fuel pins or tracer levels of activity.

\section{MECHANICAL PROCESSING}

Mechanical decladding $2,3,4$ and shear-leach ${ }^{7,12}$ methods for processing stainless-steel-clad uranium-thorium metal or oxide fuels were successfully developed and tested on a small pilot-plant scale. Mechanical decladding was used to remove the stainless steel cladding from irradiated $\mathrm{NaK}$ bonded, $2.7 \%$-enriched uranium metal Sodium Reactor Experiment Fuel (SRE, Core 1). A similar method could be used to declad the SRE Core 2 fuel (7.8\% Th-U). An engineering-scale shear-leach complex consisting of a 250-ton shear and a countercurrent leacher was successfully tested with prototype assemblies consisting of stainless-steel-clad porcelain, $\mathrm{UO}_{2}$, and $\mathrm{ThO}_{2}-\mathrm{UO}_{2}$. Nuclear Fuel Services will probably use a similar system but with a batch leacher in a commercial fuel processing plant. ${ }^{5}$ A conceptual study for installation of a shear-leach complex at the Idaho Chemical Processing Plant was completed. 6

Advantages of mechanical processing include: (1) Lower waste-disposal costs than for aqueous decladding. In a comparative cost estimate, waste costs were eight times lower for mechanically decladding ${ }^{2}$ SRE Core 1 fuel and 20 times lower for shearing and leaching ${ }^{7}$ Mcrchant Ship Savannah fuel, compared with dissolution of the stainless steel cladding in sulfuric acid (Sulfex Process). (2) Reduction of explosion hazard ${ }^{9}$ by removing liquid-metal bonds prior to aqueous fuel dissolution. (3) Shattering of $\mathrm{UO}_{2}$ or $\mathrm{ThO}_{2}-\mathrm{UO}_{2}$ fuel cores during shearing increases the amount of core which can be dissolved per unit of time because of greater surface area.

\subsection{Mechanical Decladding of SRE Fuel}

Twenty-six SRE-Core 1 irradiated fuel clusters were successfully declad at ORNL in a specially designed ${ }^{2}$ equipment complex (Fig. 1) using the steps shown in Fig. 2. The SRE Core 1 fuel consists of clusters, $105.5 \mathrm{in}$. long, of seven elements or rods 


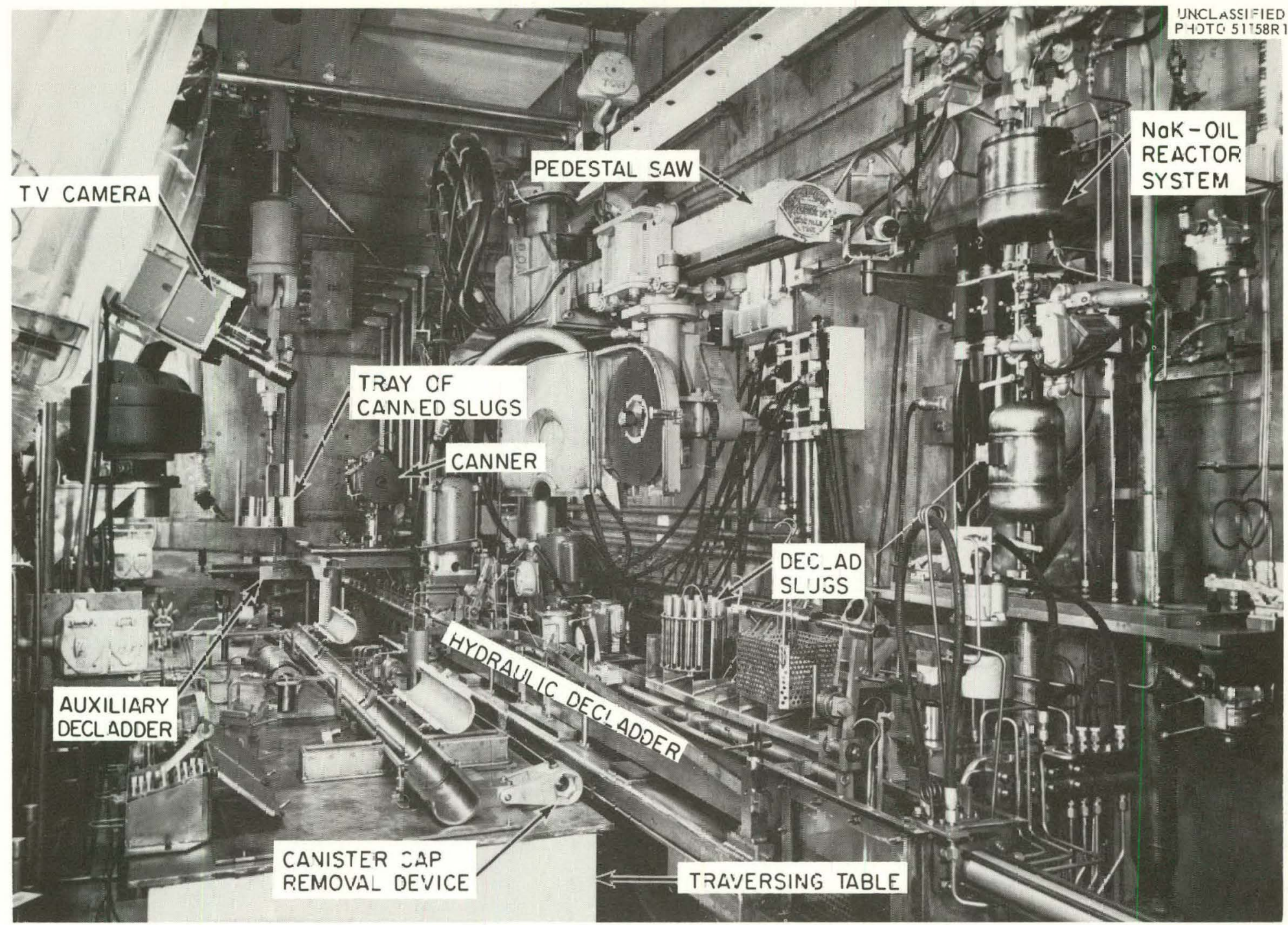

Fig. 1. Mechanical processing ezuipmert for decladding SRE Core I fuel (interior view, Cell A) ORNL segmenting facility. 


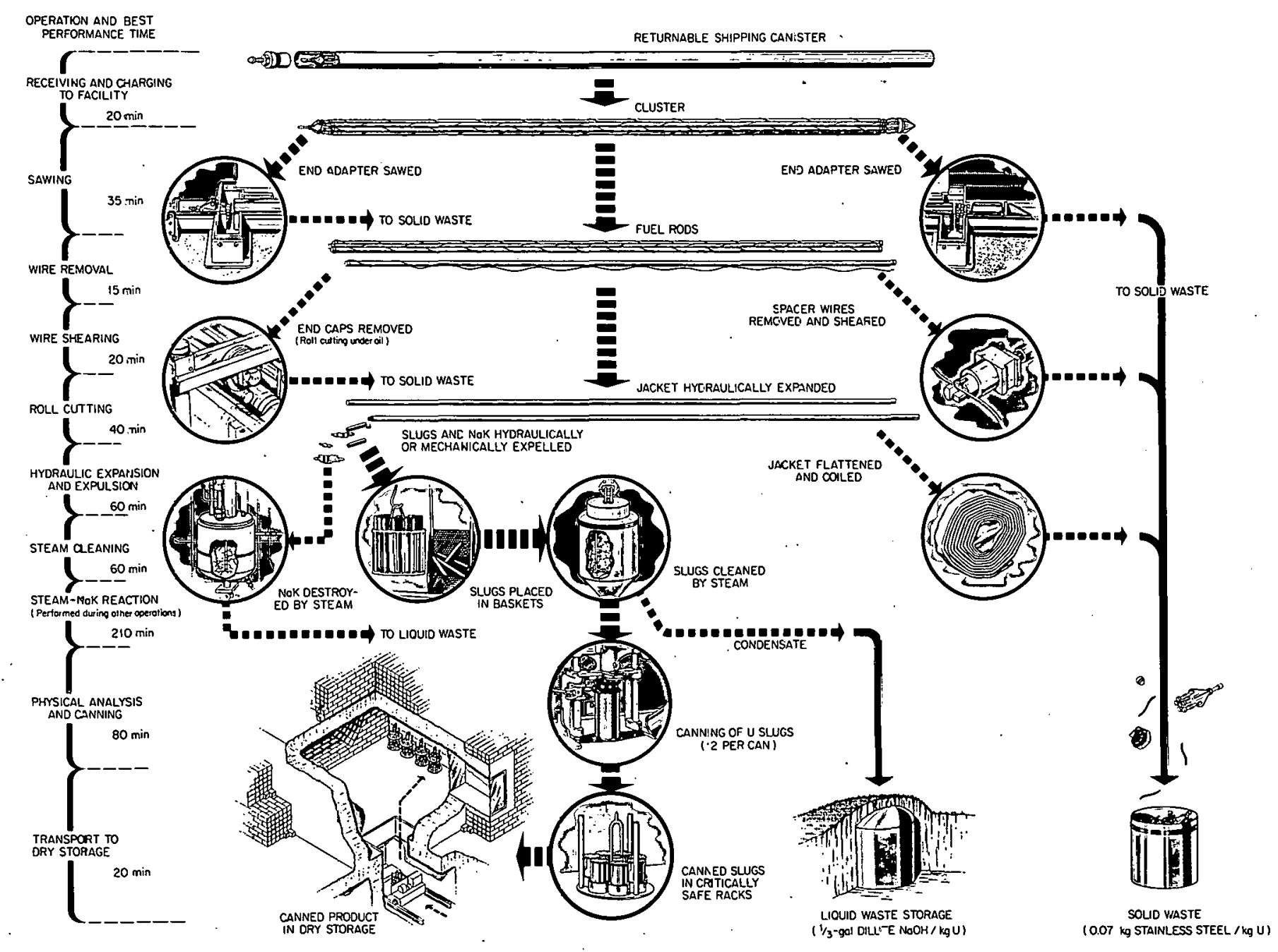

Fig. 2. Mechanical decladding of SRE fuel. 
containing $2.7 \%$ enriched uranium slugs in thin-walled (0.010 in.) type 304 stainless steel tubular cladding, 92-5/16-in. long and $0.790 \mathrm{in}$. outer diameter. The active fuel length is $72 \mathrm{in.,}$ consisting of 12 slugs, $0.750 \mathrm{in}$. in diameter and $6.0 \mathrm{in}$. long, of unalloyed uranium thermally bonded to the clad by a 0.010-in. NaK eutectic annulus. At the end of the column is a helium-filled space, approximately $18 \mathrm{in}$. high, which allows for expansion of the $\mathrm{NaK}$ bond and serves as a reservoir for fission gases. The fuel was irradiated to an average exposure of $675 \mathrm{Mwd} /$ tonne and decayed about two years. The fuel was subjected to an undesirably high temperature during a reactor incident in which organic pump coolant leaked into the sodium core coolant. 8,10 Undesirable fuel characteristics (pitted, swollen, elongated and bent fuel slugs, and partially solidified $\mathrm{NaK}$ ) were attributed to the incident. The unexpected hardness of the stainless steel may have resulted from work hardening. These characteristics complicated the decladding operation.

About 1.8 metric tonnes of fuel consisting of 175 tubular fuel rods were mechanically declad, steam cleaned, recanned, and placed in dry storage at rates of 2 to 9.2 $\mathrm{kg} \mathrm{U} / \mathrm{hr}$, with negligible loss of uranium and plutonium. Hydraulic expansion of the cladding and expulsion of the slugs, the primary method of decladding, was effective on $16 \%$ of the rods. Slugs from $77 \%$ were dislodged by a mechanical screw, the secondary processing method, and $7 \%$ had to be processed by a third method using an auxiliary roller-cutter unit followed by peeling of the clad from each fuel slug with a remotely operated manipulator. The primary and secondary methods could not adequately cope with the damaged fuel. Decladding by remote manipulation was successfully used with the damaged fuel, but it is much too time consuming to be practical.

Other stainless-steel-clad, liquid-bonded fuels, such as the SRE Core $2\left(7.8 \%\right.$ Th-U), ${ }^{8}$ can be declad mechanically if the fuel is not damaged and if the cladding remains ductile. Either hydraulic expansion or the mechanical screw methods are applicable. SRE Core 3, containing UC, could be processed similarly if the carbon content of the core remains less than stoichiometric. 11 A greater than stoichiometric amount of carbon in the fuel causes embrittlement of the cladding. 


\subsection{Shear-Leach}

The experimental shear-leach complex (Figs. 3 and 4) was designed to process subassemblies of the type used in the Yankee, Nuclear Merchant Ship "Savannah," Commonwealth Edison, Pressurized Water Reactor (blanket), Consolidated Edison (CETR), or Rural Cooperative reactors or any subassembly whose cross section does not exceed $6.36 \times 6.36 \mathrm{in}$. ORNL prototype assemblies, stainless-steel-clad ceramic "dummies," $\mathrm{ThO}_{2}$, or $\mathrm{UO}_{2}$, were used in development work (Fig. 5). The 250-ton shear, (Fig. 4) conveyor feeder, and inclined rotary leacher were successfully tested with unirradiated prototype fuel. Interlocking of the components by a fail-safe electrical system for proper operation was highly successful.

After a fuel assembly is placed in the feed envelope of the shear, the mechanical events that follow may be initiated automatically or manually. Prototype assemblies filled with $\cup_{2}$ were sheared and leached at rates of up to $12 \mathrm{~kg}$ of $U \mathrm{O}_{2} / \mathrm{hr}$. The cost of the shear was $\$ 185,000$, and the conveyor feeder and leacher were $\$ 40,000$ each. Tests in which stainless-steel-clad $\mathrm{UO}_{2}-\mathrm{ThO}_{2}$ fuel prototype assemblies were sheared into $1 / 2$ and $1 \mathrm{in}$. lengths were satisfactory, and combined shear-leach tests on unirradiated stainless-steel-clad $\mathrm{ThO}_{2}$ and Zircaloy-2-clad $\mathrm{UO}_{2}$ is scheduled for early 1963. Irradiated fuel will not be processed.

Shear. - The life of the stepped, moving shear blade (Fig. 6) is estimated at 10,000 cuts of a 36-tube ORNL Mark I assembly filled with porcelain dummies, $\mathrm{UO}_{2}$, or $\mathrm{UO}_{2}-\mathrm{ThO}_{2}$. A Squarekeen* No. 3 blade was chipped on the main tooth after 5982 cuts on porcelain-filled ORNL Mark I prototype assemblies. One side of a blade would be used to make 5000 cuts, then turned to the other side for an additional 5000 cuts. Damaged blades could be recovered by grinding the first two steps of the blade to remove the worn edges. The useful life of a single blade is probably sufficient to shear one typical reactor core into l-in. lengths.

Inner and outer "gags" (Fig. 7) were developed to hold an assembly while it is being sheared. Currently, the shortest terminal piece of fuel assembly that can be held and sheared satisfactorily is $1.5 \mathrm{in}$. long, the width of the inner gag. A 1-in.-wide

\footnotetext{
${ }^{\star}$ Composition weight percentage: $\mathrm{C}-0.53, \mathrm{Mn}-0.31, \mathrm{Si}-0.87, \mathrm{Cr}-5.00, \mathrm{Mo}-1.28$, $W-1.23, \mathrm{~S}-0.01, \mathrm{P}-0.02$; hardness, $\mathrm{RC}-54$ to 56 ; cost $\$ 250.00$.
} 


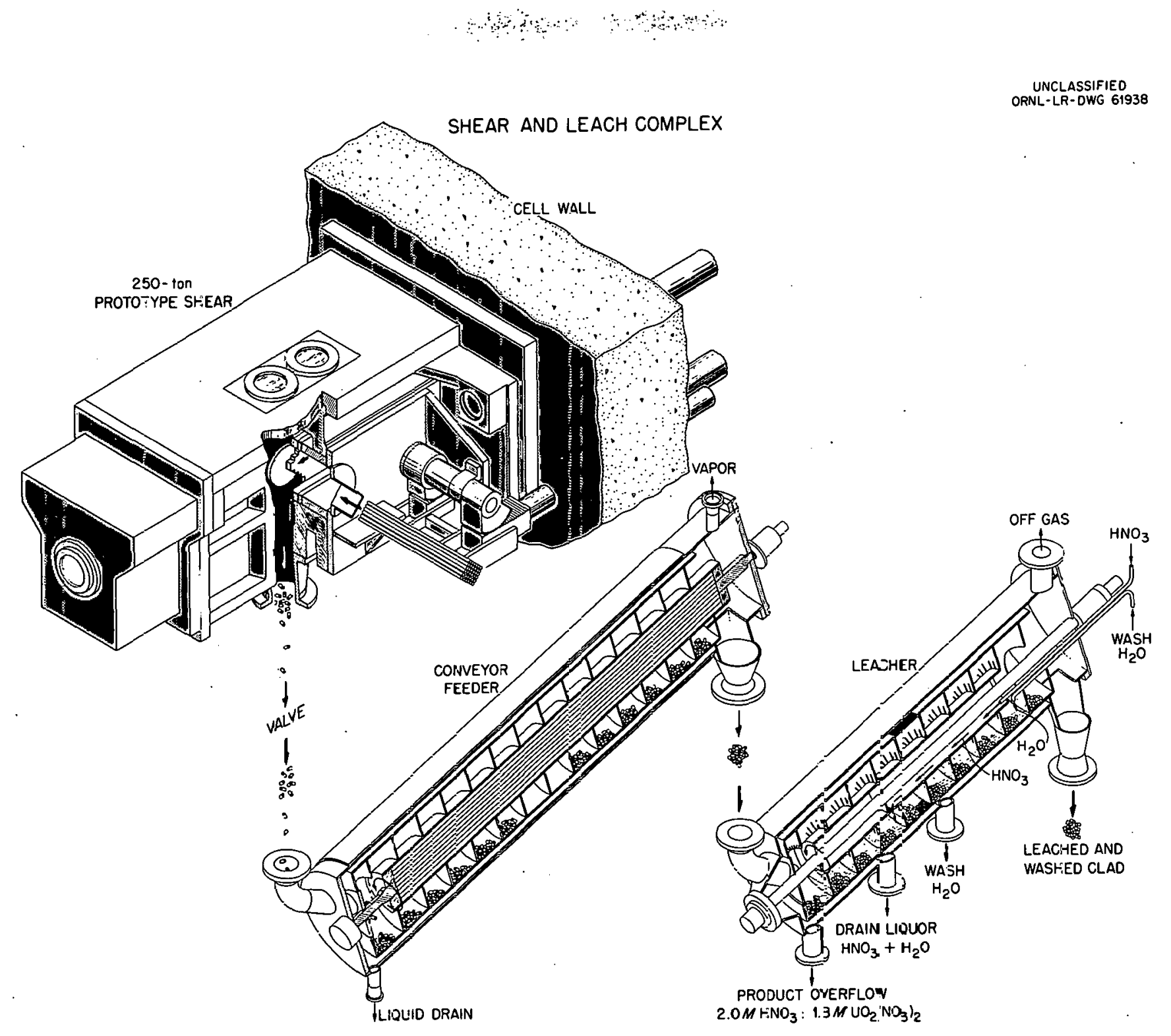

Fig. 3. Shear and leach complex. 


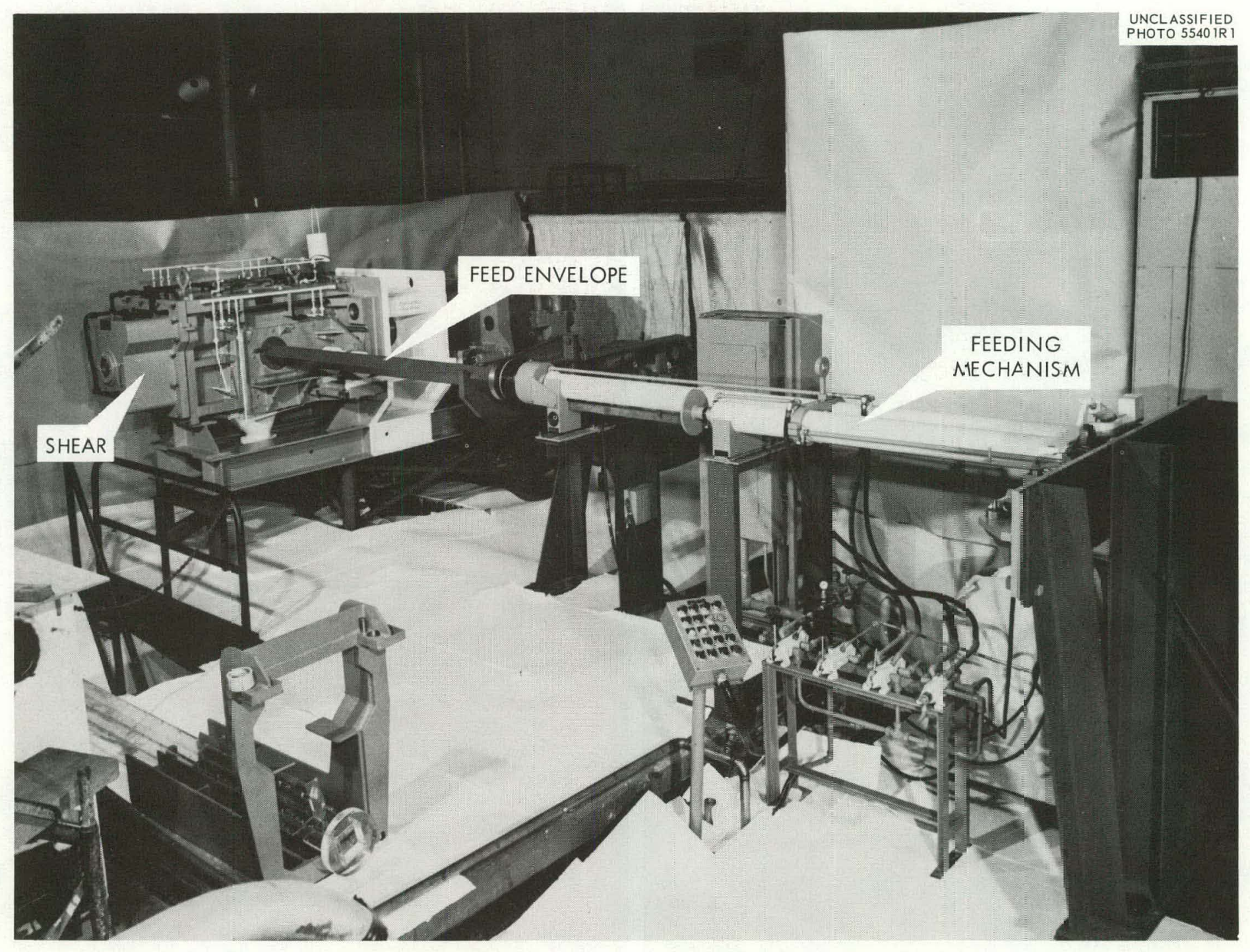

Fig. 4. ORNL 250 ton shear assembly. 


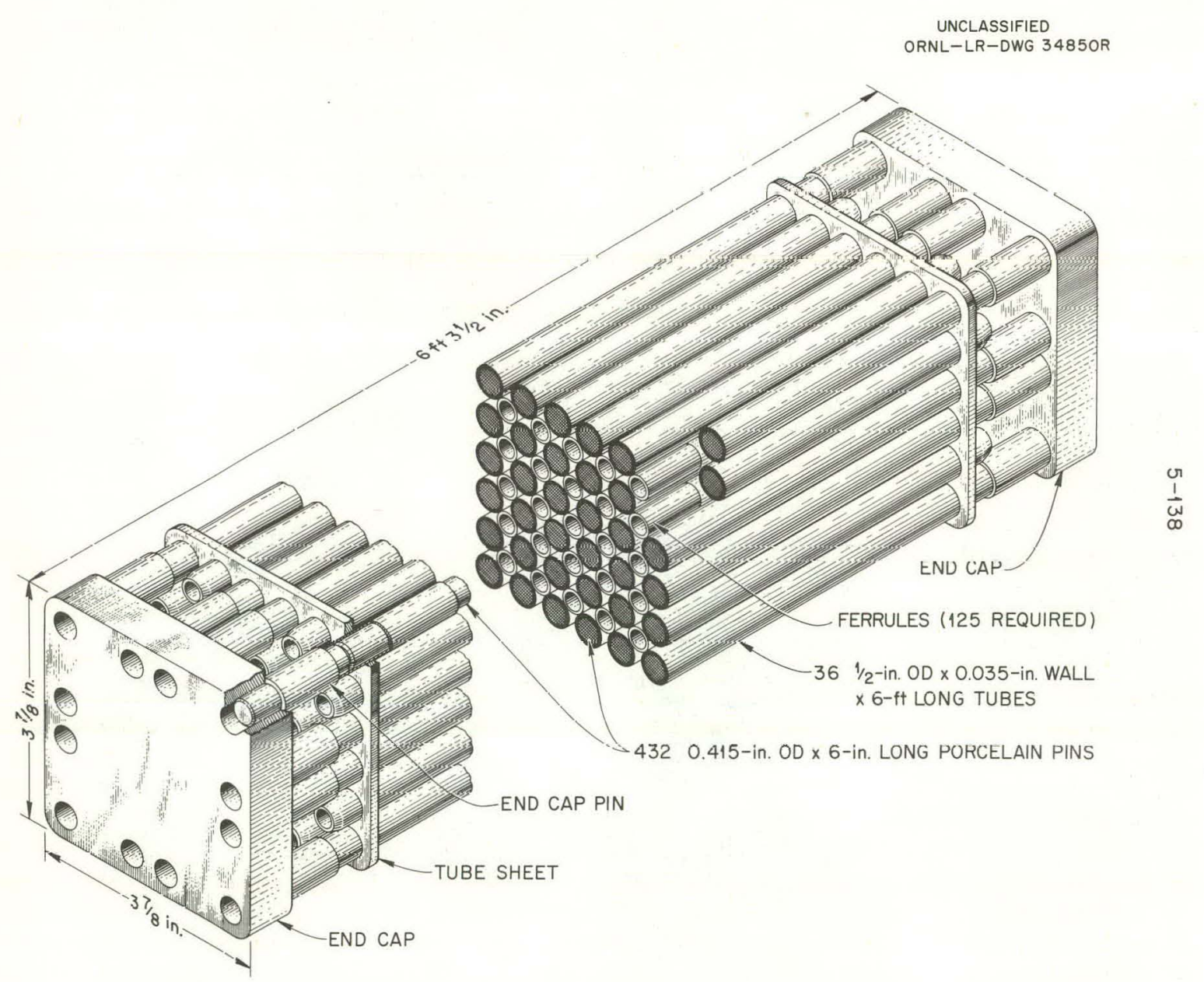

Fig. 5. Prototype fuel element Mark I. 


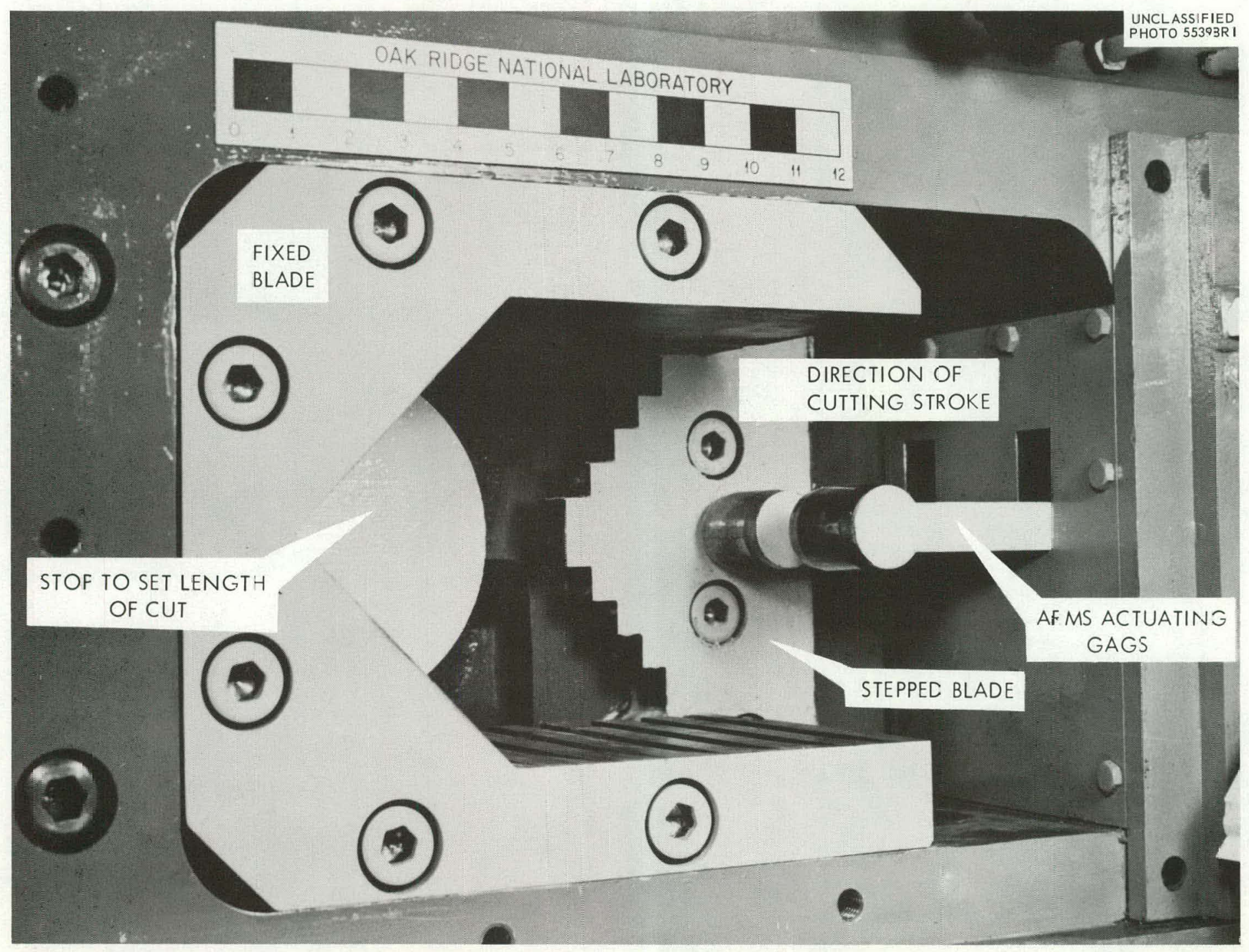

Fig. 6. Stepped shear blade for ORNL 250 ton shear. 


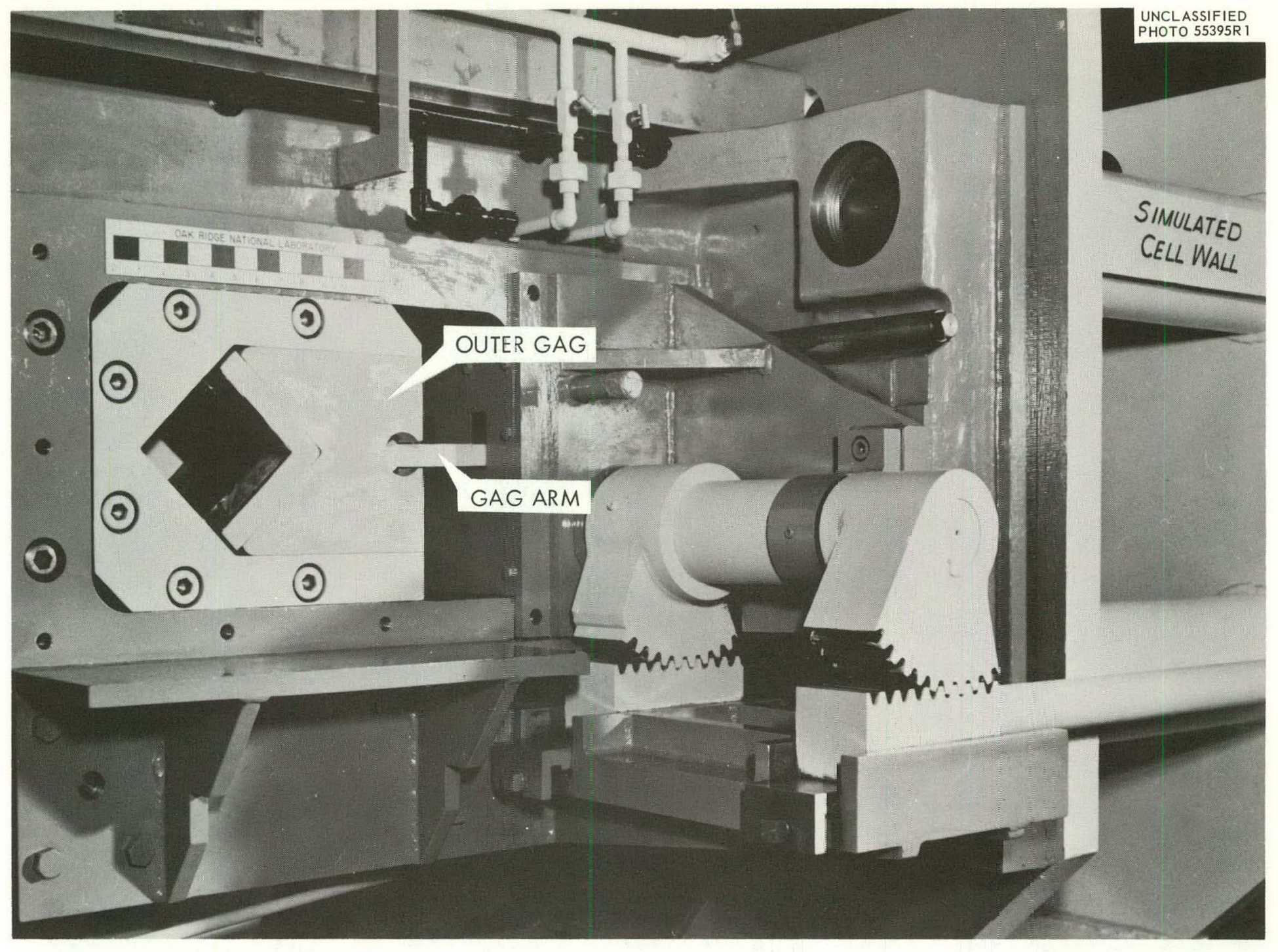

Fig. 7. Gag for ORNL 250 ton shear. 
gag will be tried. Except for this terminal-length limitation, discrete sheared lengths of $1 / 2$ to $2 \mathrm{in}$. are obtainable. Shearing of fuel into $1 / 4-i n$. lengths is not desirable because the clad is severely flattened, trapping pieces of core (Fig. 8). The shortest practical length is probably about $1 / 2$ in.

Brazed fuel assemblies having ferrules as spacers between fuel tubes are easily sheared. Unbrazed assemblies having tube sheets (Fig. 5) as spacers can be sheared as easily as brazed fuel. Near the tube sheets, however, undesirable chunks of fuel held together by the sheet itself are produced. These chunks cannot be handled in a continuous countercurrent leacher because they cannot be completely submerged in the counterflowing acid. Also, the chunks may block the flow of solids in a continuous leacher in which dimensions are minimized because of criticality considerations.

A batch leacher may be required for fuels containing tube sheets. The size distribution of particulate composites composed of cladding, core and braze metal which were dislodged during the shearing of (a) porcelain, (b) $\mathrm{UO}_{2}$, and (c) $\mathrm{UO}_{2}-\mathrm{ThO}_{2}-$ filled, ORNL stainless-steel-jacketed prototype fuel into 1/4, 1/2, 1, and 1-1/2-in. lengths are presented in Fig. 9. Curves of the particle-size distribution of each component are available. ${ }^{12}$ Generally, sheared $\mathrm{UO}_{2}$-filled and $\mathrm{UO}_{2}-\mathrm{ThO}_{2}$-filled assemblies produce equal quantities of particles. The amount of $\mathrm{UO}_{2}$ and stainless steel dislodged increases as the length of sheared pieces is decreased (Table 1).

The cladding of two porcelain-filled Mark 1 assemblies was carburized prior to shearing to simulate hardening and embrittlement of fuel cladding from neutron bombardment in a reactor. Carburization had two effects: (1) More core and clad were dislodged, Table 2 and Fig. 10, than from an untreated assembly. (2) The tonnage required was only about half that required for an uncarburized assembly. In tests by Goode, using a small single-tube shear, the amount of particles dislodged when shearing single tubes of stainless steel or Zircaloy-2 filled with $\mathrm{UO}_{2}$ pellets irradiated to approximately $16,000 \mathrm{Mwd} /$ ton $U$ did not differ significantly from the amount produced from unirradiated specimens ${ }^{13}$ ( $6 \%<10$ mesh for $1 \mathrm{in}$. of length) although the irradiated fuel pellets were shattered $(0.1 \%<10$ mesh) during the irradiation period prior to shearing. Measurements of the amount of particles contributed individually by the clad and core were not made. 


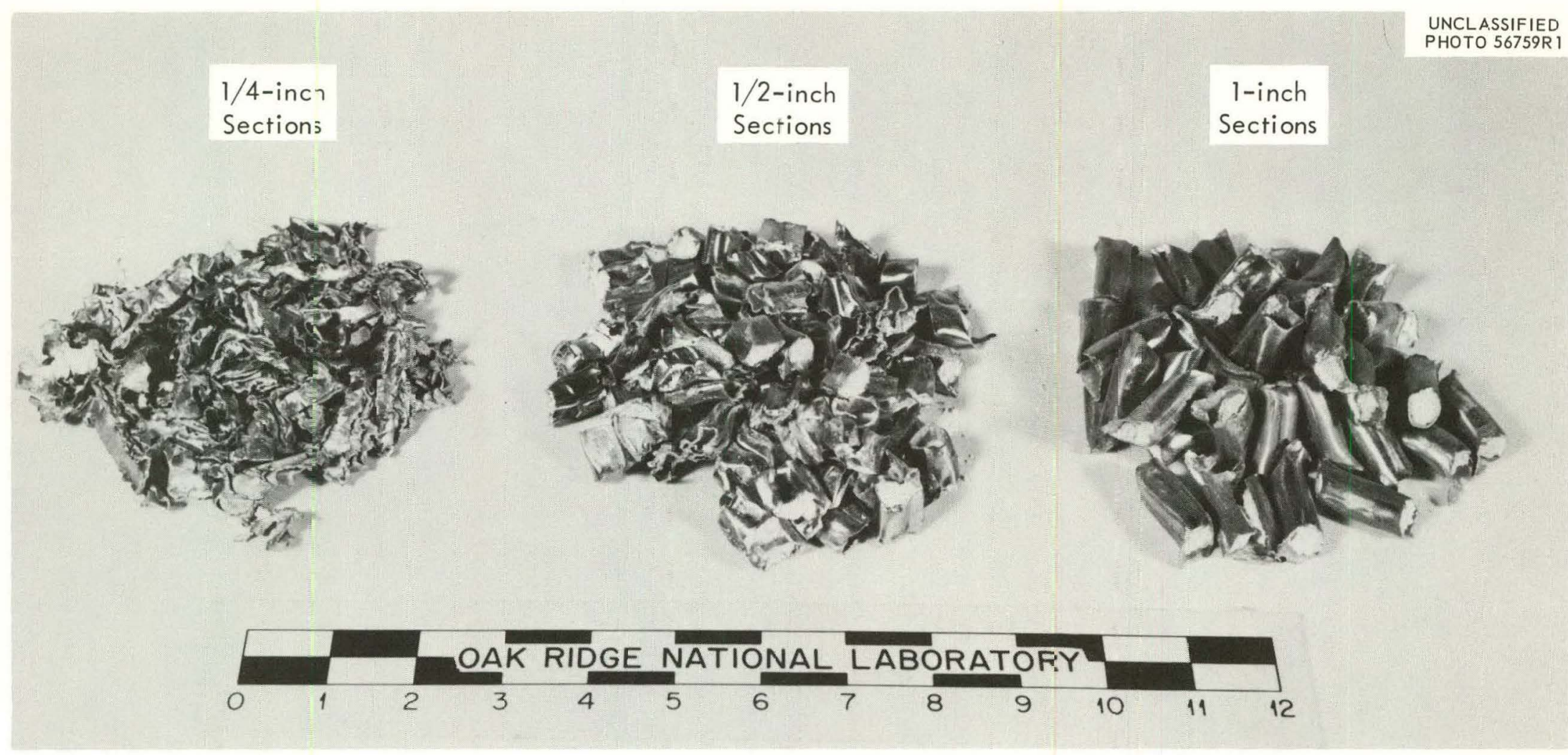

F g. 8. Comparison of stainless steel tubing when shearing a porcelain-filled ORNL Mark I prototype fuel assembly into $1 / 4-, 1 / 2-$, and 1 -inch sections using a stepped blade and ORVL 250 ton shear. Dislodged porcelain fines are not shown. 
Table 1. Distribution of $\mathrm{UO}_{2}$ and Stainless Steel Particles from a Sheared ORNL Mark 1 Fuel Assembly

ORNL Mark 1 assembly: square bundle, $3.625 \times 3.625$ in., of 36 type 304 stainless steel tubes, $1 / 2 \mathrm{in}$. $O D \times 72 \mathrm{in}$. long $\times 35 \mathrm{mil}$ wall, assembled with $1 / 4 \mathrm{in}$. $-\mathrm{OD} \times$ 1-in.-long Kanigen or Nicro brazed spacer ferrules at $12-i n$. spacing. Tubes filled with $\mathrm{UO}_{2}$ pellets, $0.420 \mathrm{in.} \mathrm{OD} \times 0.625 \mathrm{in}$. long.

\begin{tabular}{|c|c|c|c|c|}
\hline \multirow[b]{3}{*}{ Sheared Length (in.) } & \multicolumn{4}{|c|}{$\mathrm{UO}_{2}(\mathrm{~W}+\%)^{\mathrm{a}}$} \\
\hline & \multicolumn{3}{|c|}{ Dislodged } & $\begin{array}{l}\text { Retained } \\
\text { in Clad }\end{array}$ \\
\hline & $<44 \mu$ & $44-1,000 \mu$ & $1,000-9,520 \mu$ & \\
\hline 0.5 & 22.4 & 57.6 & 4.5 & 15.5 \\
\hline 1.0 & 7.35 & 25.6 & 2.4 & 64.6 \\
\hline \multirow[t]{3}{*}{1.5} & 4.5 & 12.0 & 1.2 & 82.3 \\
\hline & \multicolumn{4}{|c|}{ Stainless Steel $(W+\%)^{b}$} \\
\hline & \multicolumn{3}{|c|}{ Dislodged } & Retained \\
\hline 0.5 & 0.023 & 0.38 & 7.6 & 92.0 \\
\hline 1.0 & 0.007 & 0.12 & 2.1 & 97.8 \\
\hline 1.5 & 0.003 & 0.057 & 2.6 & 97.4 \\
\hline
\end{tabular}

Wt $\%$ computations: (a) $\frac{\text { Weight }(\mathrm{g}) \text { of } \mathrm{UO}_{2} \text { dislodged }}{\text { Weight }(\mathrm{g}) \text { of } \mathrm{UO}_{2} \text { in fuel assembly }} \times 100$

(b) $\frac{\text { Weight }(\mathrm{g}) \text { of stainless steel dislodged }}{\text { Weight (g) of stainless steel in fuel assembly }} \times 100$ 


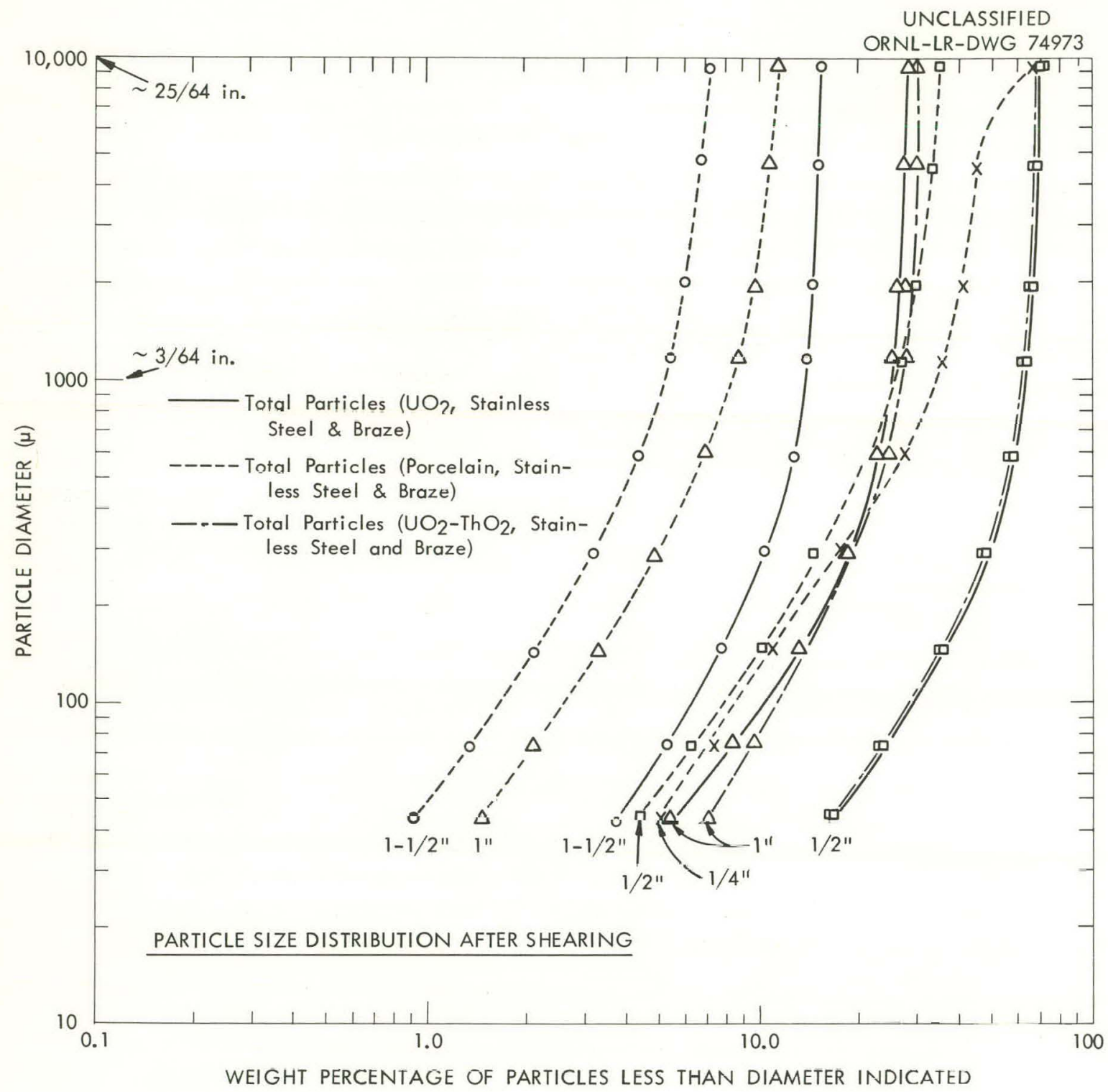

Fig. 9. Distribution of total particles smaller than $9520 \mathrm{U}$ dislodged from the shearing of porcelain, $\mathrm{UO}_{2}$, or $\mathrm{UO}_{2}-\mathrm{ThO}_{2}$-filled ORNL Mark I fuel into 1/4-, 1/2-, 1-, and $1-1 / 2-i n$. lengths. 
Table 2. Distribution of Particles from $\mathrm{UO}_{2}$, Porcelain, and Carburized Porcelain-Filled ORNL Mark 1 Fuel Assemblies Sheared into 1-in. Lengths ORNL Mark 1 assembly: square bundle $(3.625 \times 3.625$ in.) of 36 type 304 stainless steel tubes $1 / 2 \mathrm{in.} O D \times 72 \mathrm{in}$. long $\times 35 \mathrm{mil}$ wall, assembled with $1 / 4 \mathrm{in}$. $-O D \times$ 1-in.-long Kanigen or Nicro brazed spacer ferrules at $\sim 12$ in. spacing. Tubes filled with 0.420 -in. $-O D \times 3$-in.-long porcelain sections or $U_{2}$ sections, $0.420 \mathrm{in}$. $O D \times$ $0.625 \mathrm{in}$.

\begin{tabular}{|c|c|c|c|c|}
\hline \multirow[b]{3}{*}{ Core Material } & \multicolumn{4}{|c|}{ Core Material $\left(W_{+} \%\right)^{a}$} \\
\hline & \multicolumn{3}{|c|}{ Dislodged } & \multirow[t]{2}{*}{$\begin{array}{l}\text { Retained } \\
\text { in Clad }\end{array}$} \\
\hline & $<44 \mu$ & $44-1,000 \mu$ & $1,000-9,520 \mu$ & \\
\hline $\begin{array}{c}\mathrm{UO}_{2} \\
\text { (Ductile clad) }\end{array}$ & 7.4 & 25.6 & 2.4 & 64.6 \\
\hline $\begin{array}{c}\text { Porcelain } \\
\text { (Ductile clad) }\end{array}$ & 3.0 & 16.2 & 4.3 & 76.5 \\
\hline $\begin{array}{c}\text { Porcelain (Carburized } \\
0.8 \% \text { max, clad) }\end{array}$ & 3.5 & 24.0 & 16.0 & 56.5 \\
\hline & \multicolumn{4}{|c|}{ Stainless Steel $\left(W_{+} \%\right)^{b}$} \\
\hline & \multicolumn{3}{|c|}{ Dislodged } & Retained \\
\hline $\begin{array}{c}\mathrm{UO}_{2} \\
\text { (Ductile clad) }\end{array}$ & 0.007 & 0.12 & 2.1 & 97.8 \\
\hline $\begin{array}{c}\text { Porcelain } \\
\text { (Ductile clad) }\end{array}$ & 0.03 & 0.108 & 2.5 & 97.4 \\
\hline $\begin{array}{c}\text { Porcelain } \\
\text { (Carburized clad) }\end{array}$ & 0.0165 & 0.115 & 5.2 & 94.7 \\
\hline
\end{tabular}

Wt \% computations: (a) $\frac{\text { Weight }(\mathrm{g}) \text { of core material dislodged }}{\text { Weight }(\mathrm{g}) \text { of core material in fuel assembly }} \times 100$

(b) $\frac{\text { Weight }(\mathrm{g}) \text { of stainless steel dislodged }}{\text { Weight (g) of stainless steel in fuel assembly }} \times 100$ 


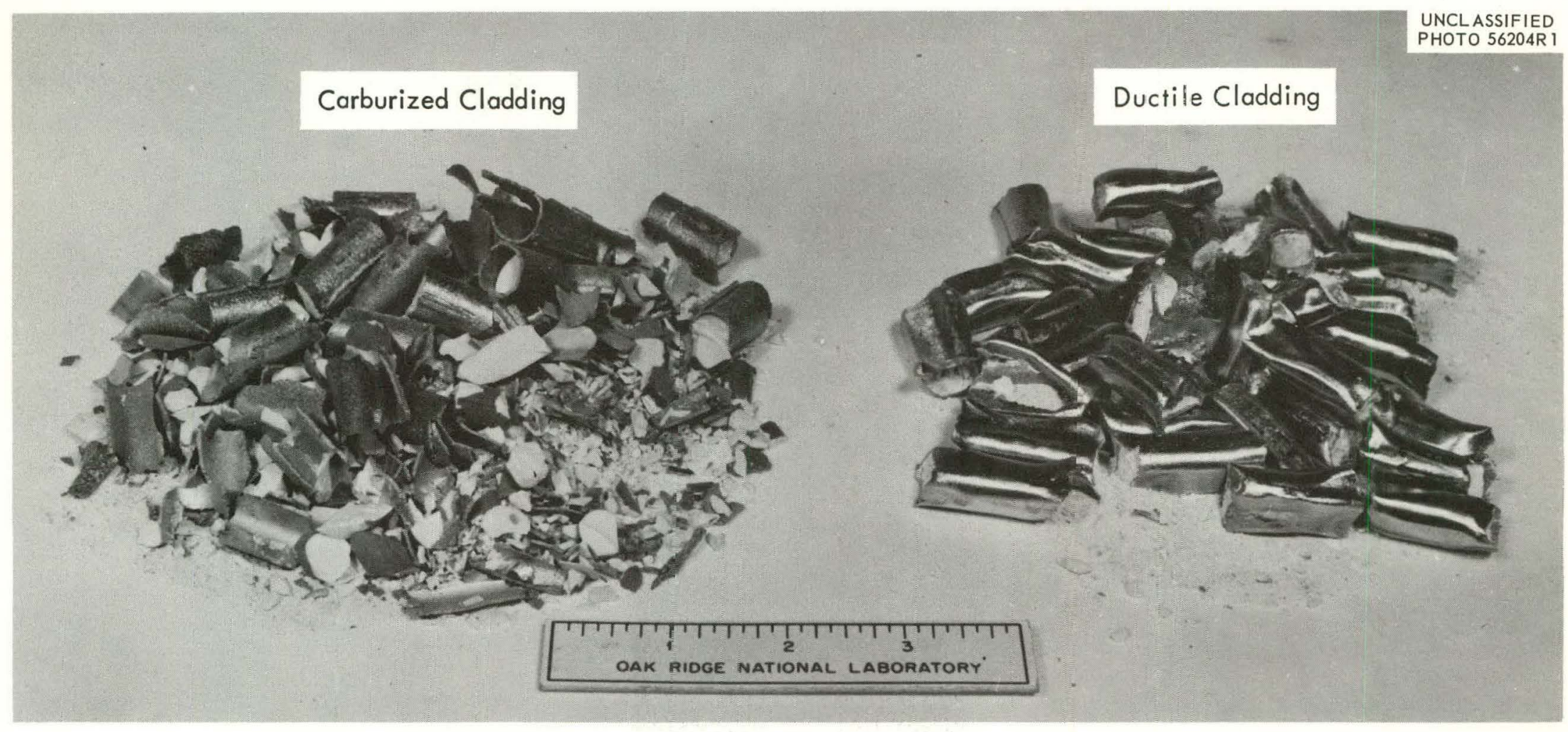

Fig. 10. Comparison of single cut made on carburized $\left(2.6 \% \mathrm{C}_{\text {max }}\right)$ and ductile stainless-steel-clad, porcelain-filled ORNL Mark I prototype fuel assemblies. 
A bellows-sealed flapper valve 14 (Fig. 11) was developed for use in the feed chutes or discharge ports of the chop-leach complex. The valve was designed to pass solids downward in the open position without constriction of the chute. When the valve is closed the flapper disk seals against rising leacher fumes by seating against an inverted fixed seat. The inverted position prevents trapping of solids and fouling of the seal. The useful life of the valve, based on one cycle per hour, was estimated from tests 14 to be about four years.

Leaching. - In the shear-leach complex, sheared fuel is leached countercurrently with boiling nitric acid in an inclined, rotary spiral leacher. The leacher consists of an inner cylinder into which is welded an internal spiral containing vertical-slot-type weirs (Fig. 3). Solids and liquid are elevated countercurrent to boiling acid flowing through the weirs. Leaching takes place in the lower four stages of the spiral, and washing of the leached clad occurs in four upper stages.

To ensure submergence of sheared fuel under the acid dissolvent, the slip angle for 1.5-, 2.25-, and 3.0-liter batches each of empty type 304L stainless steel tubing (1-in. long), solid stainless steel rod (1/2-in. in diameter $\times 1 \mathrm{in}$. long), and stainlesssteel-jacketed, porcelain-filled Mark 1 elements sheared into 1-in. lengths were measured at leacher elevations of 10,20 , and $30^{\circ}$. There was little difference in the slip angle of equal volumes of empty cladding, solid stainless steel rods, and porcelainfilled Mark 1 elements. The angle of slip increased with batch volume and less significantly with leacher elevation. At a leacher elevation of $15^{\circ}$, the slip angle increased from about 28 to $32^{\circ}$ when the batch volume increased from 1.5 to 3 liters. The optimum leacher batch size is 2.25 liters of sheared Mark 1 prototype, which is equivalent to $8 \mathrm{in}$. of length.

The slip angle is defined as the counterclockwise angle of rotation of the leacher (looking into the feed end of the leacher) sufficient to bring an originally horizontal batch to the point of slippage (Fig. 12). Slippage first occurs when approximately half of the batch is above the liquid level. To ensure submergence of chopped fuel as it is advanced each flight, the leacher is rotated $360^{\circ}$ plus the slip angle $\left(\sim 28^{\circ}\right.$ for a 2.25-liter batch) then reversed by the amount of the slip angle. 


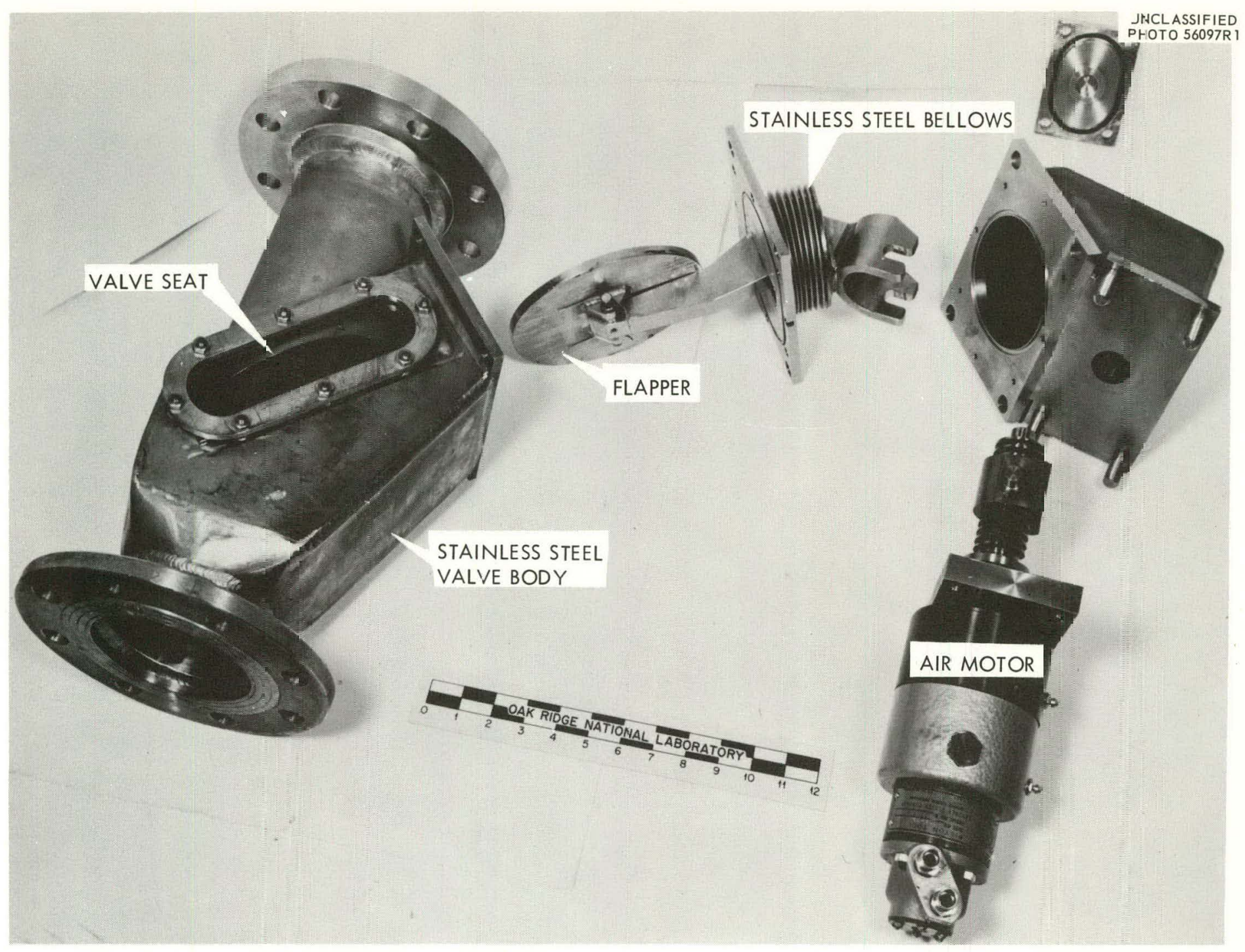

Fig. 11. Exploded view of bellows sealed flapper valve. 
UNCLASSIFIED ORNL-LR.DWG. 74840

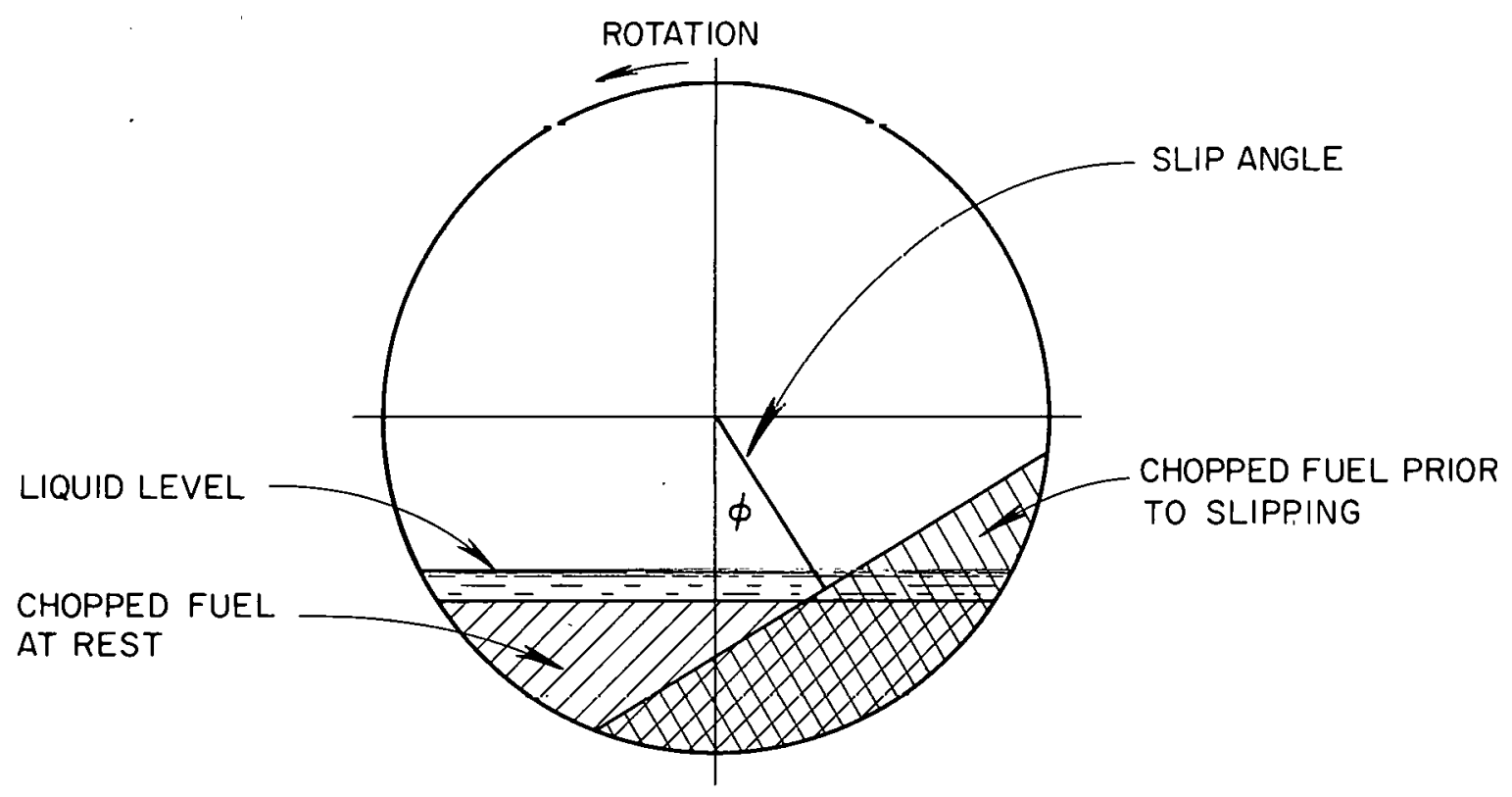

Fig. 12. Cross-section of leacher from feed end showing slip angle. 
Leaching of unirradiated $\mathrm{UO}_{2}$-filled ORNL Mark 1 prototype fuel sheared into $1 / 2,1$, and 1-1/2-in. lengths was accomplished successfully, with negligible loss of uranium. A typical curve of uranium loading ( $\mathrm{g} /$ liter) vs dissolution time $(\mathrm{min}$ ) is

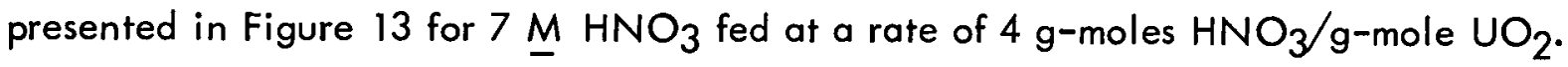
At this acid strength and ratio, apparent steady state was attained at about the fifth hour. For all sheared lengths tried, a growing inventory of $\mathrm{UO}_{2}$ was recorded (Figure 14). Increasing the acid-to- $\cup_{2}$ ratio from 4 to 6 eliminated the $\mathrm{UO}_{2}$ inventory after the third hour. Mixed $\mathrm{ThO}_{2}-\mathrm{UO}_{2}$ leach tests will be made in 1963. An increased residence time will be required to dissolve this fuel. Since both irradiated and unirradiated fragmented fuel (8-20 mesh) was $>99 \%$ dissolved in $5 \mathrm{hr}$ in batch tests 15,1 (Sec 3.1.5), a residence time of 10-15 hr should be adequate for the continuous leacher.

\section{AQUEOUS DISSOLUTION METHODS}

\subsection{Ceramic Cores Clad in Stainless Steel, Aluminum, or Zirconium}

These fuel claddings can be dissolved in a suitable reagent prior to dissolution of the oxide core in boiling $13 \underline{M} \mathrm{HNO}_{3}-0.04 \underline{M}$ HF. ${ }^{15-28}$ Two head-end processes for Thorex solvent extraction, Darex and Sulfex, were developed on a laboratory and

small engineering scale for dissolution of CETR fuel. In the Sulfex process $15-18,20,22,23$ the stainless steel cladding is dissolved in boiling 4 to $6 \mathrm{M}$ sulfuric acid, whereas the cladding is dissolved in dilute aqua regia in the Darex process. 15-17, 19,21-23 Hot-cell experiments 15,22 show that the Sulfex process will probably be satisfactory for highly irradiated elements but that losses of uranium to the decladding solution are excessive with the Darex system. The BORAX-IV core was processed 28 at the Idaho Chemical Processing Plant (ICPP) with a process 27 that involved dissolution of the aluminum cladding in $\mathrm{NaOH}-\mathrm{NaNO}_{3}$, dissolution of the lead bond in dilute nitric acid, and dissolution of the $\mathrm{ThO}_{2}-\mathrm{UO}_{2}$ core in $13 \underline{\mathrm{M} \mathrm{HNO}} 3^{--0.04} \underline{\mathrm{M} \mathrm{NaF}}$.

\subsubsection{Dissolution of Stainless Steel Cladding in Sulfuric Acid}

In the Sulfex process for CETR fuel 15-18,20,22,23 (Fig. 15), the 30-mil stainless steel cladding is dissolved in three times the stoichiometric amount of boiling 4 to $6 \mathrm{M}$ 


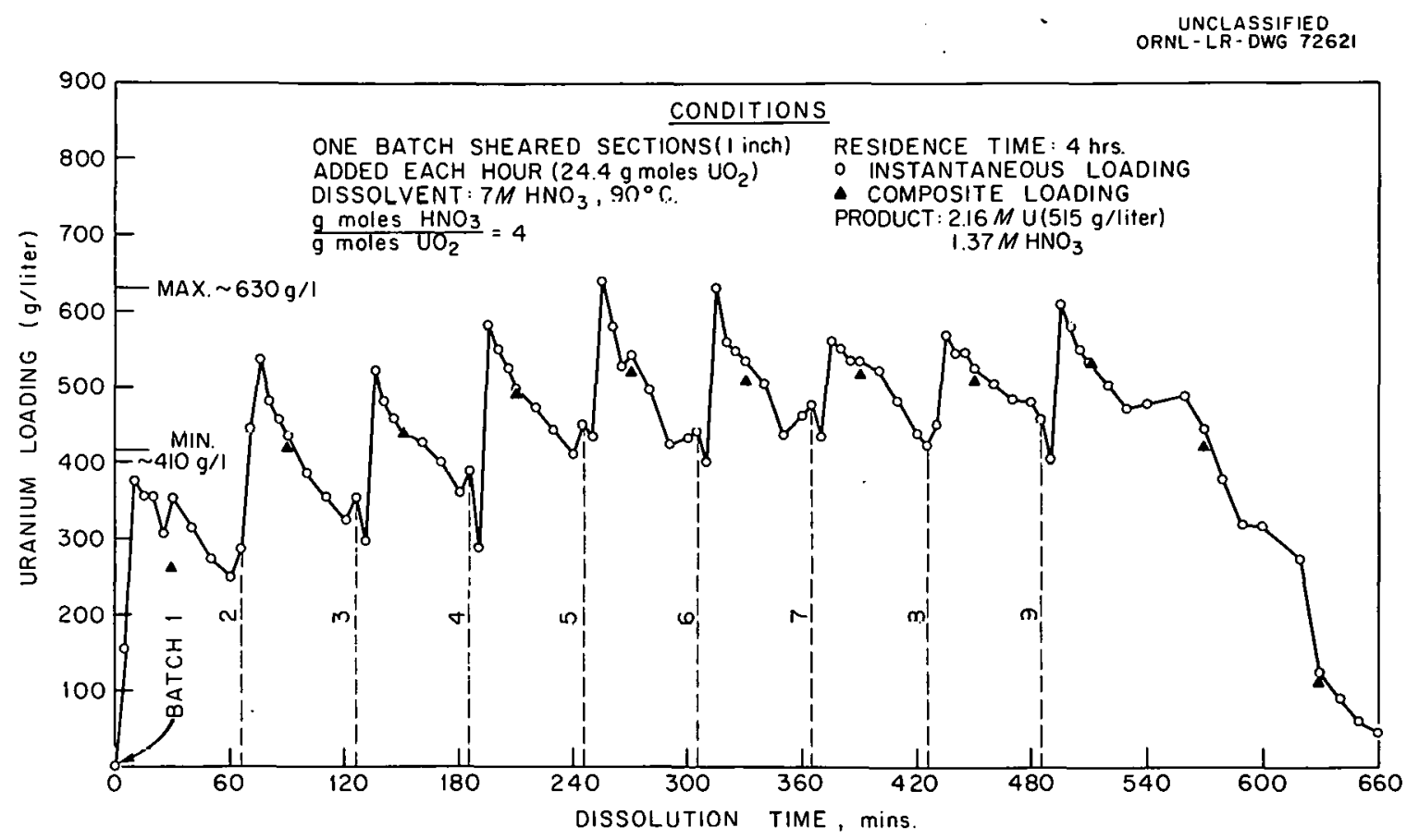

Fig. 13. Uranium loading as a function of dissolution time for a 4 stage rotary leacher. 
UNCLASSIFIED

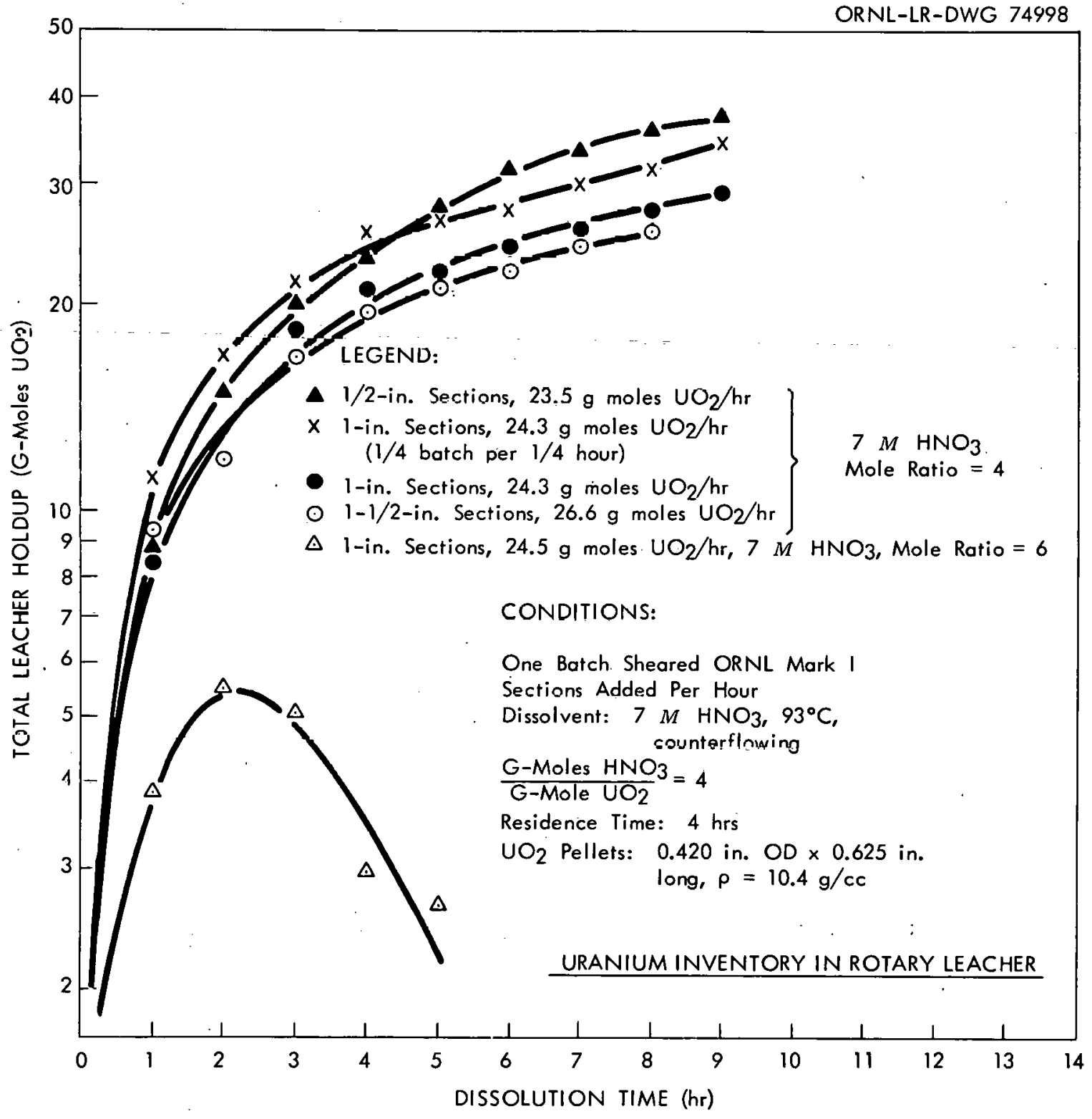

Fig. 14. Uranium inventory in rotary leacher versus dissolution time. 


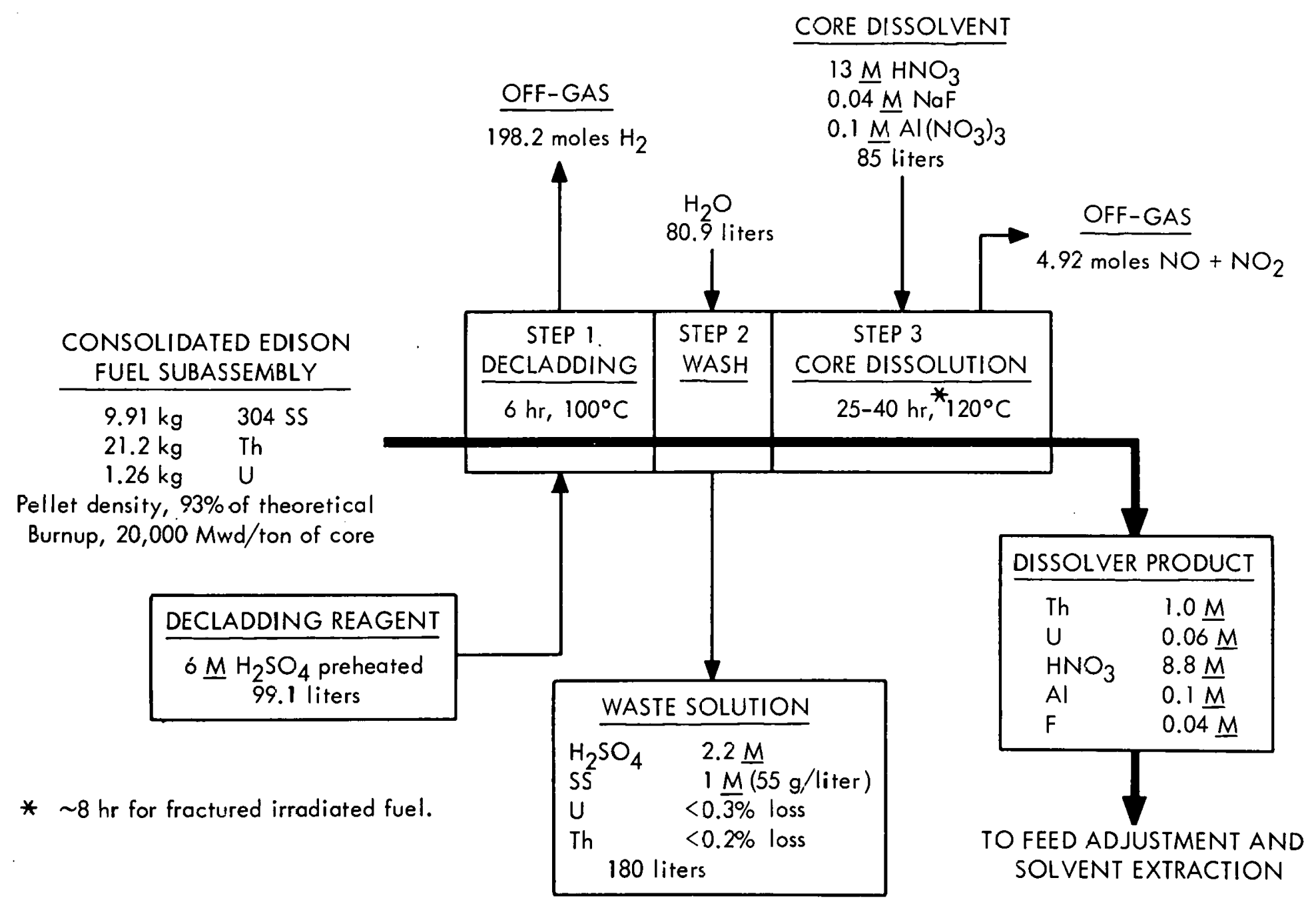

Fig. 15. Decladding and dissolution of Consolidated Edison reactor fuel by the Sulfex-Thorex process. 
$\mathrm{H}_{2} \mathrm{SO}_{4}$ in 1 to $3 \mathrm{hr}$. About 1.1 moles of hydrogen off-gas are evolved when $55 \mathrm{~g}$ ( 1 mole) of stainless steel is dissolved. The stainless steel cladding is often passive due to either a protective oxide film or traces of nitric acid in the solution. Brazed elements, however, are usually not passive. If passivation occurs, it is most conveniently broken by contacting the element with steel wool.

Losses of uranium to the decladding solution from high-density (greater than $95 \%$ of theoretical) fuel specimens were generally less than $0.3 \%$ and were not greatly affected by burnup over the range of 620 to $20,000 \mathrm{Mwd}$ per ton of core. ${ }^{15,22}$ The increase in loss with burnup is attributed to the larger surface ared present as the result of shattering of the highly irradiated fuel specimens. These results indicate that the Sulfex process will be suitable for the decladding of highly irradiated $\mathrm{ThO}_{2}-$ $\mathrm{UO}_{2}$ reactor fuels.

\subsubsection{Darex Decladding}

In the Darex process for CETR fuel ${ }^{15-17,19,21-23}$ (Fig. 16), the stainless steel cladding is dissolved in sufficient boiling $5 \underline{\mathrm{M} \mathrm{HNO}} 3^{--2} \mathrm{M} \mathrm{HCl}$ to yield a solution containing about $50 \mathrm{~g}$ of stainless steel per liter. The off-gas contains $20 \% \mathrm{NO}_{2}$, $35 \% \mathrm{NOCl}, 35 \% \mathrm{~N}_{2}$, and traces of $\mathrm{N}_{2} \mathrm{O}, \mathrm{NO}, \mathrm{HCl}, \mathrm{Cl}_{2}$, and $\mathrm{H}_{2}$. Dissolution of a 30-mil-thick cladding requires about $2 \mathrm{hr}$.

The uranium loss to the Darex decladding solutions was excessively high from highly irradiated CETR fuel specimens; 15,22 the loss increased from 0.15 to $5 \%$ as the burnup increased from 0 to 20,000 Mwd per ton of core. Fragmentation of the fuel pellets undoubtedly contributed to the high losses, but the losses were higher than expected from fragmentation alone. If the Darex process is used, the uranium and thorium can be recovered in the Acid Thorex solvent extraction system (see Sec 4.).

\subsubsection{Aluminum Dissolution}

Aluminum cladding from $\mathrm{ThO}_{2}-\mathrm{UO}_{2}$ fuels such as the BORAX-IV is readily dissolved $^{27}$ in $\mathrm{NaOH}-\mathrm{NaNO}_{3}$ solutions, with a uranium loss of less than $0.2 \%$. The BORAX-IV fuel, which contained a lead bond between the $\mathrm{ThO}_{2}-\mathrm{UO}_{2}$ fuel and the 


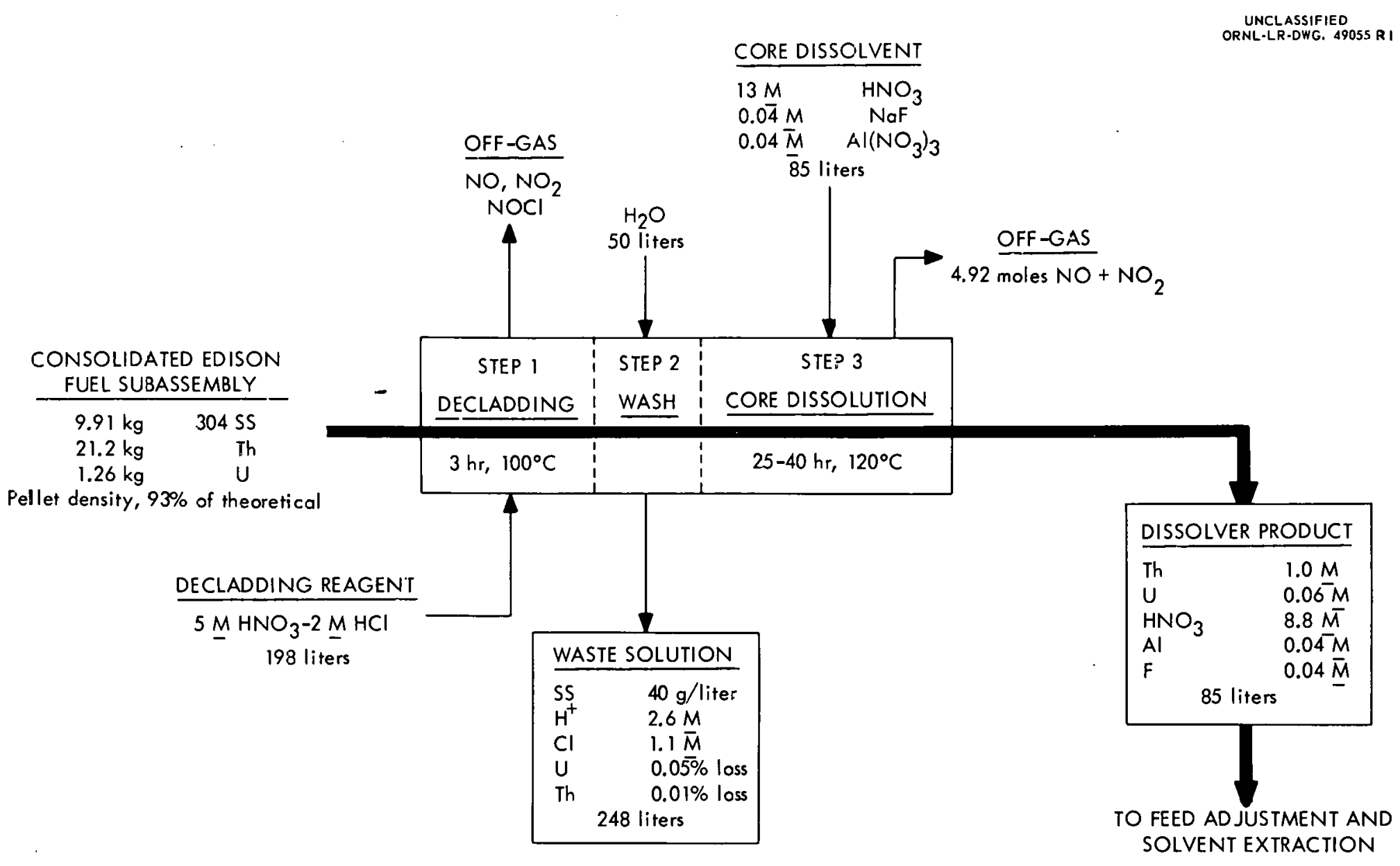

Fig. 16. Decladding and dissolution of Consolidated Edison reactor fuel by the Darex-Thorex process. 
aluminum cladding, was processed at ICPP 28 by the method developed at ORNL. 27 The aluminum cladding was dissolved in caustic, and the lead bond was dissolved in dilute nitric acid prior to dissolution of the core in $13 \underline{M} \mathrm{HNO}_{3}-0.04 \underline{M} \mathrm{HF}$.

\subsubsection{Zirconium Dissolution}

Preliminary experiments ${ }^{1}$ with unirradiated $\mathrm{ThO}_{2}-\mathrm{UO}_{2.7}$ fuel specimens $(4.2 \%$ $\mathrm{UO}_{2.7}, 83 \%$ of theoretical density) indicated that the zirconium cladding could be dissolved in boiling $6 \underline{\mathrm{M} N \mathrm{NH}_{4} \mathrm{~F}--1} \underline{\mathrm{M} N \mathrm{NH}_{4} \mathrm{NO}_{3} \text { (Zirflex process }}{ }^{24-26}$ ), with attendant uranium and thorium losses of less than $0.4 \%$. Losses would undoubtedly be even lower with higher-density $\cup_{2.0}$ fuel pellets.

\subsection{5 $\mathrm{ThO}_{2}-\mathrm{UO}_{2}$ Core Dissolution}

Thorium metal, thorium oxide, and $\mathrm{ThO}_{2}-\mathrm{UO}_{2}$ mixtures dissolve in boiling nitric acid containing small amounts of hydrofluoric acid as catalyst. 1, 17,29 Dissolution of high-density fuel pellets (greater than $90 \%$ of theoretical) in the optimum reagent, $13 \underline{M} \mathrm{HNO}_{3}^{--0.04} \underline{\mathrm{M} \mathrm{HF}}$, is relatively slow, however. In three times the stoichiometric amount of this reagent, 25 to $40 \mathrm{hr}$ are required to dissolve completely typical 0.26-in.-diam CETR fuel pellets.

The rate of dissolution of $\mathrm{ThO}_{2}-\mathrm{UO}_{2}$ mixtures containing up to $10 \% \mathrm{UO}_{2}$ depends on the nitric acid concentration, the hydrofluoric acid concentration, the thorium concentration in solution, and the density and state of subdivision of the mixture. When other variables are constant, the rate is maximum when the nitric acid and hydrofluoric acid concentrations are 13 and about $0.06 \underline{M}$, respectively. The instantaneous dissolution rate decreases by a factor of about 5 as the thorium concentration in solution

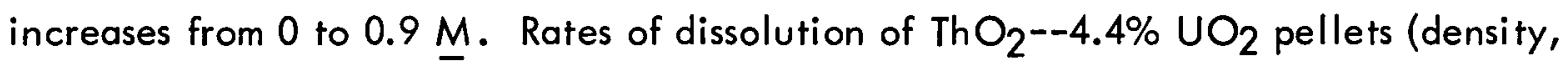
$95 \%$ of theoretical) in solutions containing $0.04 \mathrm{M} \mathrm{NaF}$ were correlated by:

$R=0.627\left(\frac{M}{10}\right)^{3}-0.336\left(\frac{M}{10}\right)^{4}-0.12\left(\frac{M}{10}\right)^{3} M_{T h}$

where $R$ is reaction rate, $\mathrm{mg} \mathrm{g}^{-1} \mathrm{~min}^{-1} ; M$ is nitric acid concentration in the dissolvent, molarity; and $M_{T h}$ is thorium concentration in the dissolvent, molarity. The dissolution 
rate of $\mathrm{ThO}_{2}--5 \% \mathrm{UO}_{2}$ pellets decreases with increasing pellet density; the initial rate in boiling $13 \underline{\mathrm{M}} \mathrm{HNO}_{3}-0.04 \underline{\mathrm{M}} \mathrm{NaF}-0.1 \underline{\mathrm{M} \mathrm{Al}}\left(\mathrm{NO}_{3}\right)_{3}$ decreased from 18 to about $1 \mathrm{mg} \mathrm{min}^{-1} \mathrm{~cm}^{-2}$ as the pellet density increased from 60 to $95 \%$ of theoretical. The rates of dissolution of $\mathrm{ThO}_{2}$ and $\mathrm{ThO}_{2}-\mathrm{UO}_{2}$ pellets containing up to $10 \% \mathrm{UO}_{2}$ were practically the same when the other conditions, such as pellet density, were constant. 23

Fused $\mathrm{ThO}_{2}$, as expected, dissolved more slowly than material of lower density. For example, in 5-hr experiments with -4 to +8 mesh samples, only about $30 \%$ of the fused $\mathrm{ThO}_{2}$ sample dissolved in a $200 \%$ excess of boiling $13 \underline{\mathrm{M} \mathrm{HNO}} 3^{--0.04}$ M NaF-$0.1 \mathrm{M} \mathrm{Al}\left(\mathrm{NO}_{3}\right)_{3}$, compared with $88 \%$ of a sample of $95.8 \% \mathrm{ThO}_{2}--\mathrm{UO}_{2} .36$ which was $93 \%$ of theoretical density. 23 Both unirradiated and irradiated (15,000-20,000 Mwd/T) 8- to 20-mesh fuel samples were greater than $99 \%$ dissolved in a 5-hr reaction with a $200 \%$ excess of boiling $13 \underline{\mathrm{M}} \mathrm{HNO}_{3}-0.01 \mathrm{M}$ NaF--0.1 $\mathrm{M} \mathrm{Al}\left(\mathrm{NO}_{3}\right)_{3}$. The smali residue was dissolved in a second digestion with fresh reagent. ${ }^{15}$ Soluble neutron poisons, $\mathrm{H}_{3} \mathrm{BO}_{3}$ or $\mathrm{Cd}\left(\mathrm{NO}_{3}\right)_{2}$, can be added to the dissolvent in concentrations up to 0.1 and $0.075 \underline{M}$, respectively, without affecting the rate of dissolution.

\subsection{Graphite-Base Fuel Elements}

Advanced graphite-base reactor fuel elements will probably contain 150 to 400 $\mu$-diam $\mathrm{UC}_{2}-\mathrm{ThC}_{2}$ fuel particles coated with 25 to $60 \mu$ of pyrolytic carbon dispersed throughout a graphite matrix. Representative fuels are the HTGR and the PBR. Several aqueous methods for processing graphite-base fuels have been investigated. $30-33$ For elements containing coated fuel particles, however, only two methods appear applicable. These are: burning in oxygen followed by dissolution of the $\mathrm{ThO}_{2}-\mathrm{U}_{3} \mathrm{O}_{8}$ ash in boiling $13 \underline{M} \mathrm{HNO}_{3}-0.04 \underline{\mathrm{M} \mathrm{F}}$, or fine grinding, probably to 200 mesh to ensure rupture of all the fuel particles, followed by acid leaching to recover the uranium and thorium. At present, the combustion-dissolution approach appears more attractive since both fine grinding and separation of the leach liquor from the residual fines by filtration or centrifugation are difficult. An extensive study has been made of the reactions of thorium and uranium carbides and graphite with $\mathrm{H}_{2} \mathrm{O}, \mathrm{HCl}, \mathrm{H}_{2} \mathrm{SO}_{4}$, or $\mathrm{HNO}_{3} .34,35$ 


\subsubsection{Combustion-Dissolution}

Combustion (in oxygen at temperatures above $700^{\circ} \mathrm{C}$ ) of graphite-base fuels followed by dissolution of the oxide ash leads to quantitative recovery of uranium and thorium from fuels containing carbon-coated fuel particles 32,33 (Table 3 ). This method may also be applicable to fuels containing BeO-coated particles, using procedures developed for the dissolution of sintered $\mathrm{BeO} ; 36$ however, alumina-coated fuels probably cannot be processed by an aqueous method because of the chemical inertness of sintered $\mathrm{Al}_{2} \mathrm{O}_{3}$. The $\mathrm{Al}_{2} \mathrm{O}_{3}$-coated particles remain virtually intact after burning and would have to be crushed to allow recovery of the uranium and thorium by an aqueous dissolution process.

Considerably more effort will be required to develop fully the combustiondissolution method. Particular attention will be given to methods for treating the radioactive off-gas, to design of the burner (preferably one in which both burning and dissolution can be conducted), and to the evaluation of materials of construction suitable for the burner.

Table 3. Uranium and-Thorium Recovery from Graphite-Base Fuels by the Combustion-Dissolution Process

Conditions: Fuel burned in oxygen at $700-900^{\circ} \mathrm{C}$; ash digested for 6 to $10 \mathrm{hr}$ in boiling reagent

\begin{tabular}{|c|c|c|c|c|c|}
\hline \multirow[b]{2}{*}{ Fuel } & \multicolumn{2}{|c|}{ Fuel Comp. (\%) } & \multirow[b]{2}{*}{ Leachant } & \multicolumn{2}{|c|}{ Recoveries (\%) } \\
\hline & Uranium & Thorium & & Uraniurin & Thorium \\
\hline Uncoated $U \mathrm{CC}_{2}-\mathrm{ThC}_{2}$ & 1.7 & 8.0 & $\begin{array}{l}13 \mathrm{M} \mathrm{HNO}_{3}^{--} \\
0 . \overline{04} \mathrm{M} \mathrm{HF--} \\
0.1 \mathrm{M} \mathrm{Al}\left(\mathrm{NO}_{3}\right)_{3}\end{array}$ & 100 & 100 \\
\hline $\begin{array}{l}\text { Pyrolytic carbon- } \\
\text { coated } \mathrm{UC}_{2}-\mathrm{Th}_{2}\end{array}$ & 9.9 & 33.0 & $\begin{array}{l}13 \mathrm{M} \mathrm{HNO} \mathrm{HN}_{3}^{--} \\
0 . \overline{04} \mathrm{M} \mathrm{HF}-- \\
0.1 \mathrm{M} \mathrm{Al}\left(\mathrm{NO}_{3}\right)_{3}\end{array}$ & 100 & 100 \\
\hline $\mathrm{Al}_{2} \mathrm{O}_{3}$-coated $\mathrm{UO}_{2}$ & 8.0 & 0.0 & $10 \mathrm{M} \mathrm{HNO}_{3}$ & 9.9 & --- \\
\hline
\end{tabular}




\subsubsection{Fine Grinding Followed by Acid Leaching}

- After a fuel that contains carbon-, $\mathrm{BeO}-$, or $\mathrm{Al}_{2} \mathrm{O}_{3}$-coated fuel particles is ground fine enough (about 200 mesh) to ensure rupture of the particles, the uranium and thorium can be recovered 32,33 by leaching with either nitric acid or a mixture of nitric and hydrofluoric acids (Table 4). Digestion for 6 to $8 \mathrm{hr}$ with the boiling reagent is required to effect high recoveries. It is probable that hydrofluoric acid will be required in the reagent to ensure adequate recoveries, although there are too few data to allow a final conclusion.

Table 4. Uranium and Thorium Recovery from Graphite-Base Fuels by the Grind-Leach Process

Cunditions: Fuel ground to 200 mesh and leached for 6 to $8 \mathrm{hr}$ with boiling reagent

\begin{tabular}{|c|c|c|c|c|c|}
\hline & \multicolumn{2}{|c|}{ Fuel Comp. (\%) } & \multirow[b]{2}{*}{ Leachant } & \multicolumn{2}{|c|}{ Recoveries (\%) } \\
\hline Fuel & Uranium & Thorium & & Uranium & Thorium \\
\hline $\mathrm{Al}_{2} \mathrm{O}_{3}$-coated $\mathrm{UO}_{2}$ & 8.0 & 0.0 & $15.8 \underline{\mathrm{M} \mathrm{HNO}} 3$ & 99 & -- \\
\hline $\begin{array}{l}\text { Pyrolytic carbon- } \\
\text { coated } \mathrm{UC}_{2}-\mathrm{ThC}_{2}\end{array}$ & 9.7 & 33.8 & $15.8 \underline{M} \mathrm{HNO}_{3}$ & $\sim 99$ & 99.9 \\
\hline $\begin{array}{l}\text { Pyrolytic carbon- } \\
\text { coated } U C_{2}-T h C_{2}\end{array}$ & 9.6 & 33.5 & $\begin{array}{c}13 \mathrm{MHNO} \mathrm{HNO}^{--} \\
0 . \overline{\mathrm{O}} \mathrm{M} \mathrm{HF}-- \\
0.1 \mathrm{M} \text { Al(NO }\end{array}$ & $\begin{array}{r}99.4 \\
\text { 3) } 3\end{array}$ & 99.9 \\
\hline
\end{tabular}

Two major problems remain to be solved with the grind-leach process. First, the feasibility of grinding coated-particle fuels to the desired fineness on a large engineering scale must be demonstrated. Second, suitable equipment must be designed for separation of the solids from the acidic leach slurries by centrifugation or filtration.

\subsubsection{Reactions of Thorium and Uranium Carbides with Water and Nitric Acid}

Reactions of thorium and uranium carbides in various aqueous reagents are being studied to provide basic process data. 34,35 Hydrolysis of uranium and thorium carbides in water at $80^{\circ} \mathrm{C}$ results in the formation of the respective solid hydrous oxides and mixtures of hydrogen and hydrocarbons. The nature of the hydrocarbon products depends on the carbide being hydrolyzed. The two monocarbides, ThC and UC, yield a gas consisting of $83 \%$ methane and $13 \%$ hydrogen on hydrolysis. All the carbide 
carbon is converted to gaseous products (Table 5). In contrast, hydrolysis of the higher carbides, $\mathrm{U}_{2} \mathrm{C}_{3}, \mathrm{ThC}_{2}, \mathrm{UC}_{2}$, results in much less gas evolution. However, the gas contains $30-40 \% \mathrm{C}_{2}-\mathrm{C}_{8}$ hydrocarbons and $50-80 \%$ hydrogen. Furthermore, $50-80 \%$ of the carbide carbon remains as nonvolatile carbon compounds. Hydrolysis of the respec-

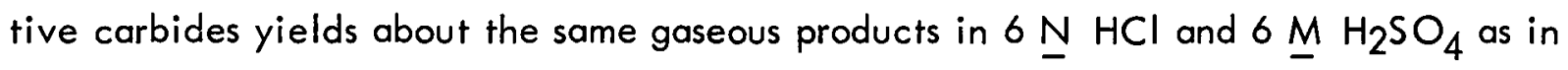
water. On the other hand, reaction of $\mathrm{UC}$ with $4 \underline{\mathrm{M}} \mathrm{HNO}_{3}$ gives completely different results. The off-gas is comprised mainly of $\mathrm{NO}$ and $\mathrm{CO}_{2}$ and contains no hydrogen or hydrocarbon gases (Table 6). In addition, 30-50\% of the carbide carbon remains in solution as a mixture of oxalic, benzene polycarboxylic, and higher-molecular-weight organic acids. No insoluble wax is formed. The soluble acids should not constitute a process hazard, however, since they are not nitrated. Similar reactions are expecled between other uranium and thorium carbides with nitric acid, but quantitative studies have not been completed. Initial tests show that no solid or waxy residues are formed.

The most reactive carbides are UC, ThC, and $\mathrm{ThC}_{2}$, and they hydrolyze completely in a few hours at $80^{\circ} \mathrm{C}$, whereas about $24 \mathrm{hr}$ are required for $\mathrm{U}_{2} \mathrm{C}_{3}$ and $\mathrm{UC}_{2}$ at the same temperature (Fig. 17). Specific reaction rates cannot be obtained because samples (3-4 g each) disintegrate to powder within approximately $30 \mathrm{~min}$. But in any event the rate of reaction of massive pieces is not dangerously fast under any conditions, even at the boiling point. At room temperature, as expected, the rates of reaction are much lower. For example, complete hydrolysis of 3- to 4-g samples of UC and ThC requires about a week at $25^{\circ} \mathrm{C}$. 34

The data given above indicate that the best method for processing sodium-bonded UC or UC-ThC fuels clad in a metal such as stainless steel is shearing followed by steaming or reaction with liquid water to destroy the bond and hydrolyze the carbide core. With stoichiometric or substoichiometric carbides, all the carbide carbon will be evolved, and the hydrous oxide residue from the steaming operation will dissolve readily in nitric acid, yielding a solution free from organics. However, if the fuel contains higher carbides, waxes will remain from the steaming operation. These waxes react with nitric acid to yield as-yet-unidentified organic products. These organic products could be a mixture of acids similar to that obtained from the UC- $\mathrm{HNO}_{3}$ reaction; in this case, there should be no problem presented to further processing. 


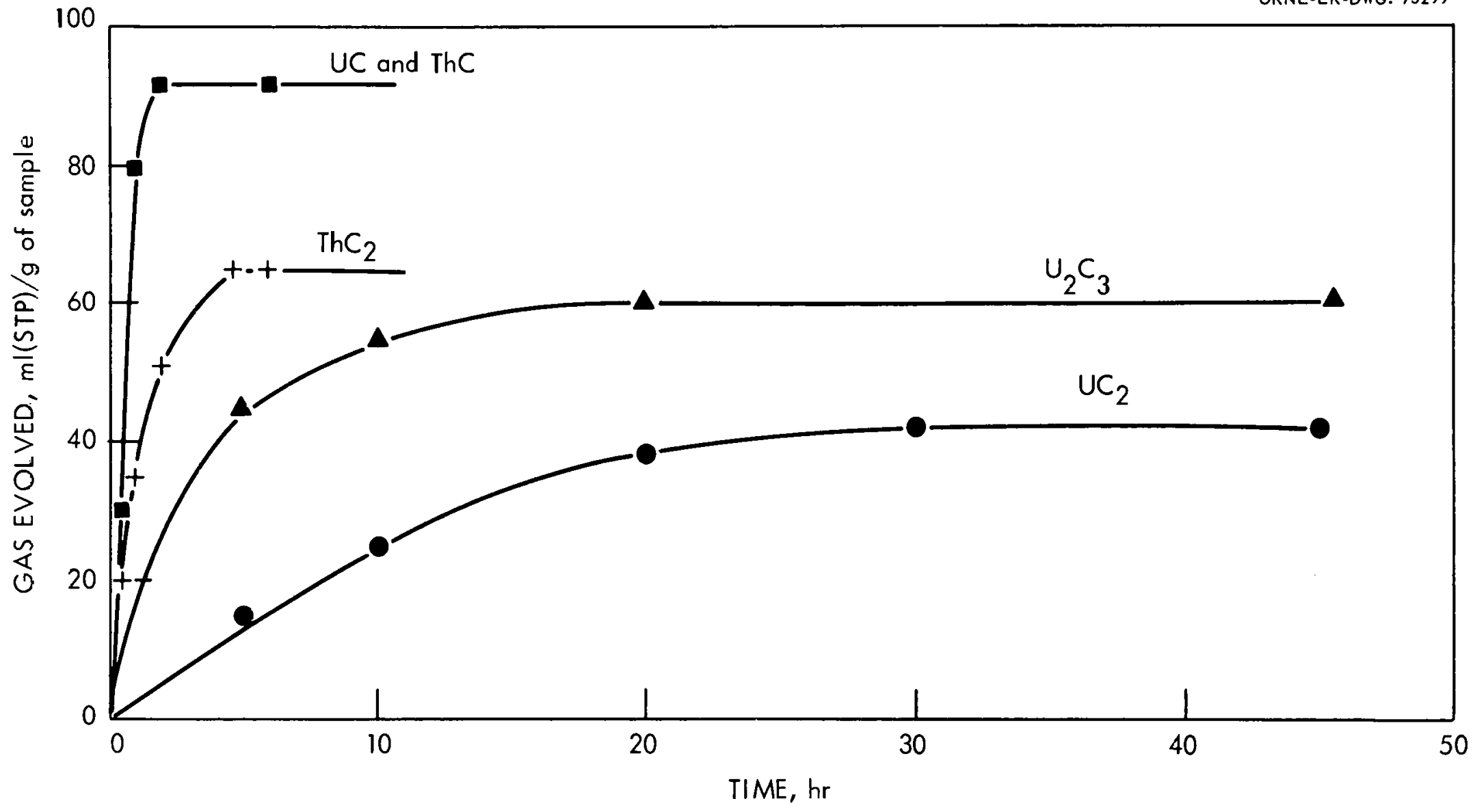

Fig. 17. Relative rates of hydrolysis at $80^{\circ} \mathrm{C}$ of 3 to $4 \mathrm{~g}$ samples of uranium and thorium carbides in water. 
Table 5. Hydrolysis of Thorium and Uranium Carbides in Water at $80^{\circ} \mathrm{C}$

\begin{tabular}{|c|c|c|c|c|c|}
\hline & \multicolumn{5}{|c|}{ Type of Carbide } \\
\hline & $\overline{U C}$ & ThC & $\mathrm{U}_{2} \mathrm{C}_{3}$ & $\mathrm{UC}_{2}$ & $\mathrm{ThC}_{2}$ \\
\hline $\begin{array}{l}\text { Volume of gas evolved, } \\
\text { ml (STP) per gram of carbide }\end{array}$ & 96 & 92 & 61 & 44 & 65 \\
\hline \multicolumn{6}{|l|}{ Composition of off-gas, vol \% } \\
\hline Hydrogen & 13 & 13 & 58 & 45 & 78 \\
\hline Methane & 84 & 82 & 2.5 & 15 & 1.5 \\
\hline Saturated $C_{2}-C_{8}$ hydrocarbons & 2.4 & 3.5 & 32 & 31 & 8.1 \\
\hline Unsaturated hydrocarbons & 0.3 & 1.3 & 7.7 & 9.0 & 12.4 \\
\hline $\begin{array}{l}\text { Nonvolatile carbon compoünds; } \\
\% \text { of original carbon }\end{array}$ & 0 & $2-$ & -48 & -67 & 77 \\
\hline
\end{tabular}

Table 6. Reaction of UC with $4 \underline{\mathrm{M}} \mathrm{HNO}_{3}$

\begin{tabular}{|c|c|c|}
\hline Product & $\begin{array}{c}\% \text { of Total Carbon } \\
\text { in Product }\end{array}$ & Product Composition \\
\hline Off-gas & $50-70$ & $\begin{array}{l}77 \% \mathrm{NU}_{;} 19 \% \mathrm{CO}_{2} ; 4 \% \mathrm{~N}_{2} \mathrm{O} \\
\text { trace } \mathrm{CO} ; \text { no hydrogen or hydro- } \\
\text { carbons. }\end{array}$ \\
\hline $\begin{array}{l}\text { Soluble organic } \\
\text { acids }\end{array}$ & $30-50$ & $\begin{array}{l}20-30 \% \text { mellitic acid; } 5-10 \% \text { oxalic } \\
\text { acid; remainder, benzene and poly- } \\
\text { nuclear polycarboxylic acids; product } \\
\text { is not nitrated. }\end{array}$ \\
\hline
\end{tabular}

The reaction of graphite with nitric acid was also studied briefly because of its importance in processes involving the nitric acid leaching of powdered graphite-base fuels. Reaction is very slow: With finely powdered graphite, only $60-80 \%$ of the carbon reacted in $500 \mathrm{hr}$ with boiling $16 \mathrm{~N} \mathrm{HNO}_{3}$. Less than $2 \%$ reacted in $24 \mathrm{hr}$, with up to $20 \%$ of the reacted carbon remaining in solution as a mixture of benzene and 
higher-molecular-weight polycarboxylic acids. As in the case of the UC-HNO reaction, the products were not nitrated and should not constitute a hazard to the process.

\section{SOLVENT EXTRACTION}

"Acid" solvent extraction processes have been developed for the extraction of uranium-233 (Acid Interim 23 process) ${ }^{37}$ or co-extraction of uranium and thorium (Acid Thorex process) 38 from nitric acid solutions with tributyl phosphate (TBP) or di-sec-butyl phenyl phosphonate (DSBPP). These processes are designed for systems where criticality is a major problem, and they differ from previous flowsheets ${ }^{39}$ in that nitric acid is used as the salting agent, rather than aluminum. Decontamination and uranium or thorium recovery with the "Acid" processes are equal to those of the older methods. Advantages include a large reduction in evaporated waste volumes because of elimination of aluminum and, in the case of the Acid Thorex process, a reduction of stage heights in extraction columns by factors of 2 to 4.40

\section{1 Acid Thorex Process}

In the Acid Thorex process, both uranium and thorium are extracted from the fission-product-bearing nitric acid solution (Fig. 18). Protactinium-233, present at short cooling times, is not extracted. Aluminum is present $(0.1 \mathrm{M})$ as a complexing agent for fluoride, added in the previous dissolution step, and is therefore not effective as a salting agent. The volume of the evaporated waste is a tenth that from the Interim 23 process. Decontamination factors obtained were 1000, 5000, 1000, and 105, respectively, for ruthenium, zirconium-niobium, protactinium, and rare earths. Uranium and thorium losses were 0.01 and $0.3 \%$, respectively. A high (30\%) TBP concentration is required to extract both uranium and thorium, and, consequently, an aciddeficient feed is used to counteract the increased tendency for extraction of fission products. When an acid feed was used, decontamination was reduced by a factor

greater than 10.41 The high decontamination achieved with the acid-deficient feed is attributed to the slow conversion of the ruthenium, zirconium-niobium, and protactinium from highly inextractable species present in acid-deficient systems to the highly extractable species formed in the acid sections of the column. 
UNCL ASSIFIED

ORNL-LR-DWG. 74838

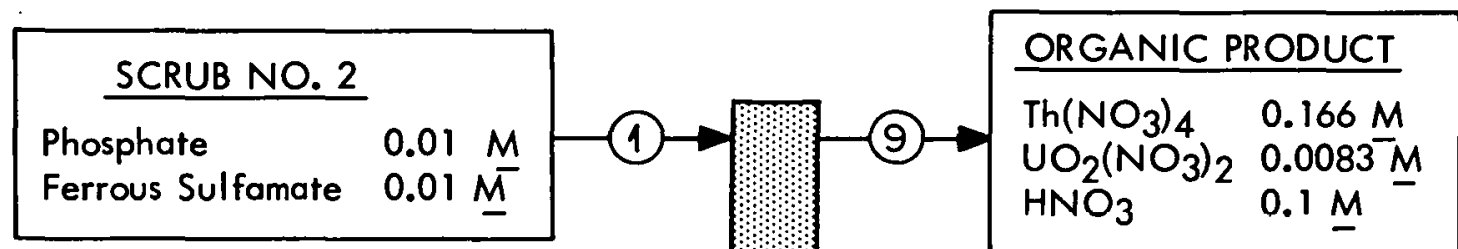

\section{SCRUB NO. 1 $\mathrm{HNO}_{3} \mathrm{JM}$}

\begin{tabular}{|ll|}
\hline \multicolumn{1}{r|}{ FEED } & \\
$\mathrm{Th}\left(\mathrm{NO}_{3}\right)_{4}$ & $1.5 \mathrm{M}$ \\
$\mathrm{UO} \mathrm{NO}_{2}\left(\mathrm{NO}_{3}\right)_{2}$ & $0.07 \overline{\mathrm{M}}$ \\
Acid Deficient & $0.1 \mathrm{~N}$ \\
$\mathrm{HF}$ & $0.04 \mathrm{M}$ \\
$\mathrm{Al}\left(\mathrm{NO}_{3}\right)_{3}$ & $0.1 \mathrm{M}$ \\
$\mathrm{NaHSO}_{3}$ & $0.05^{-} \mathrm{M}$ \\
\hline
\end{tabular}

\section{SALTING AGENT}

$\mathrm{HNO}_{3}$

$13 \underline{M}$

$$
\begin{array}{ll}
\frac{2}{2} \text { SOLVENT } \\
\text { TBP } & 30 \mathrm{v} / \mathrm{o} \\
\text { n-dodecane } & 70 \mathrm{v} / \mathrm{o}
\end{array}
$$
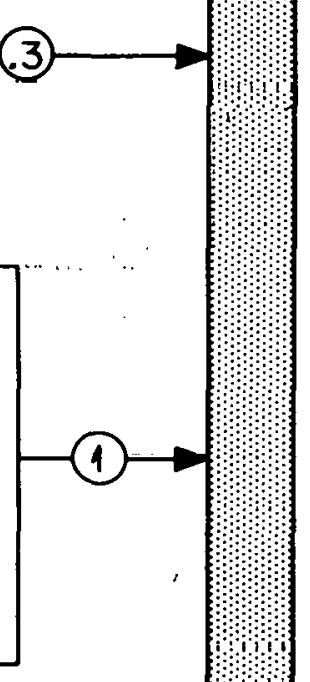

LOSSES TO AQUE OUS RAFFINATE

DECONTAMINATION FACTORS

$R_{1, i} P_{n} \quad 1000$

$\mathrm{Zr}, \mathrm{Nb} 5000$

TRE

$10^{5}$

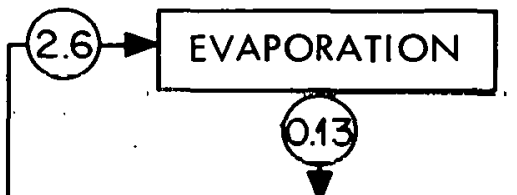

CONCENTRATED AQUEOUS RAFFINATE

$\mathrm{HNO}_{3} \sim 2 \mathrm{M}$

Aluminum $\quad 1.4 \bar{M}$

Sulfate $\quad 1.5 \bar{M}$

( $\mathrm{F}, \mathrm{Fe}, \mathrm{Na}, \mathrm{PO}_{4}, \overline{\text { etc. }}$.)

Fission and Corrosion Products

$0.2 \mathrm{I} / \mathrm{kg}$ Thorium Processed

Fig. 18. Acid Thorex process. 
In laboratory countercurrent experiments, the fission products contacted the aqueous phase for approximately $20 \mathrm{~min}$. In pulse columns this time would be reduced to about $8 \mathrm{~min}$. The two scrub solutions shown in the flowsheet combine to form a

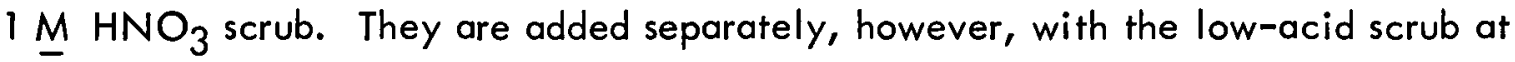
the top of the column to minimize extraction of acid with the organic product. Thus, the thorium and uranium may be costripped in a single column with minimum aqueous volume and number of stages. If the thorium and uranium are recovered separately in partitioning and strip columns, a single $1 . \mathrm{MNO}_{3}, 0.01 \mathrm{M} \mathrm{PO}_{4}{ }^{3-}$, $0.01 \mathrm{M} \mathrm{Fe}\left(\mathrm{NH}_{2} \mathrm{SO}_{3}\right)_{2}$ scrub solution at a relative flow rate of 1.3 is satisfactory.

\subsection{Acid Interim 23 Process}

An Acid Interim 23 process was developed ${ }^{37}$ to extract $U^{233}$ and leave the thorium with the fission products (Fig. 19). Protactinium-233, present at short cooling times, also remains with the fission products. After the $\mathrm{Pa}^{233}$ has decayed to $U^{233}$, the wastes can be re-extracted by the same process to recover the $U^{233}$ (and thorium, if desired, using the Acid Thorex process). The flowsheet shows the use of 5\% TBP to illustrate a high processing rate. This is close to the maximum rate, since third-phase formation occurred with 10\% TBP. In equipment in which criticality is not controlled by geometry, $2.5 \%$ TBP is used to limit the $U^{233}$ concentration in the organic phase. Uranium loss was less than $0.01 \%$, and the gross decontamination factor was approximately $10^{5}$. Advantages of the Interim 23 process include (1) rapid recovery of $U^{233}$ and resultant low invenloly churge and (2) high processing rate. Principal disadvantages are the necessity of processing the fission product and organic-degradation-product-bearing waste solution a second time to recover $\mathrm{Pa}^{233}$ and the relatively large waste volume.

\subsection{Kilorod Program}

A solvent extraction flowsheet was developed 42 for purifying recovered $U^{233}$ to be used in the fabrication of fuel elements by the Sol-Gel process 43 (Fig. 20). In laboratory countercurrent batch extraction experiments, the uranium was decontaminated from $\mathrm{Th}^{228}$ by a factor of greater than $10^{4}$. Di-sec-butyl phenyl phosphonate (DSBPP) is used rather than TBP because the separation factors for U/Th are 
UNCLASSIFIED

NRNI. I. R=nWG. 74837

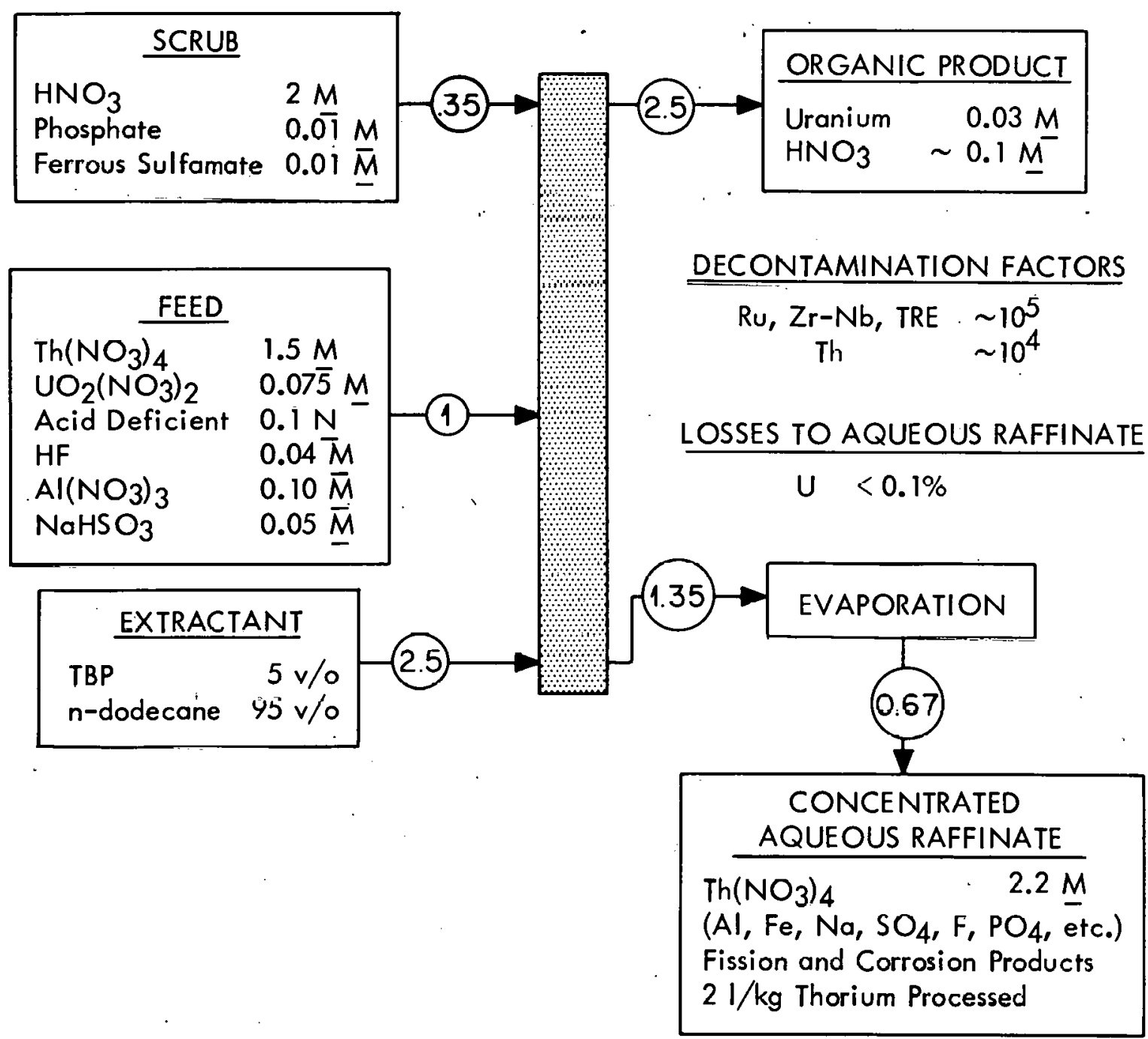

Fig. 19. Acid Interim-23 process. 
UNCLASSIFIED

ORNL.LR-DWG. 74020R1

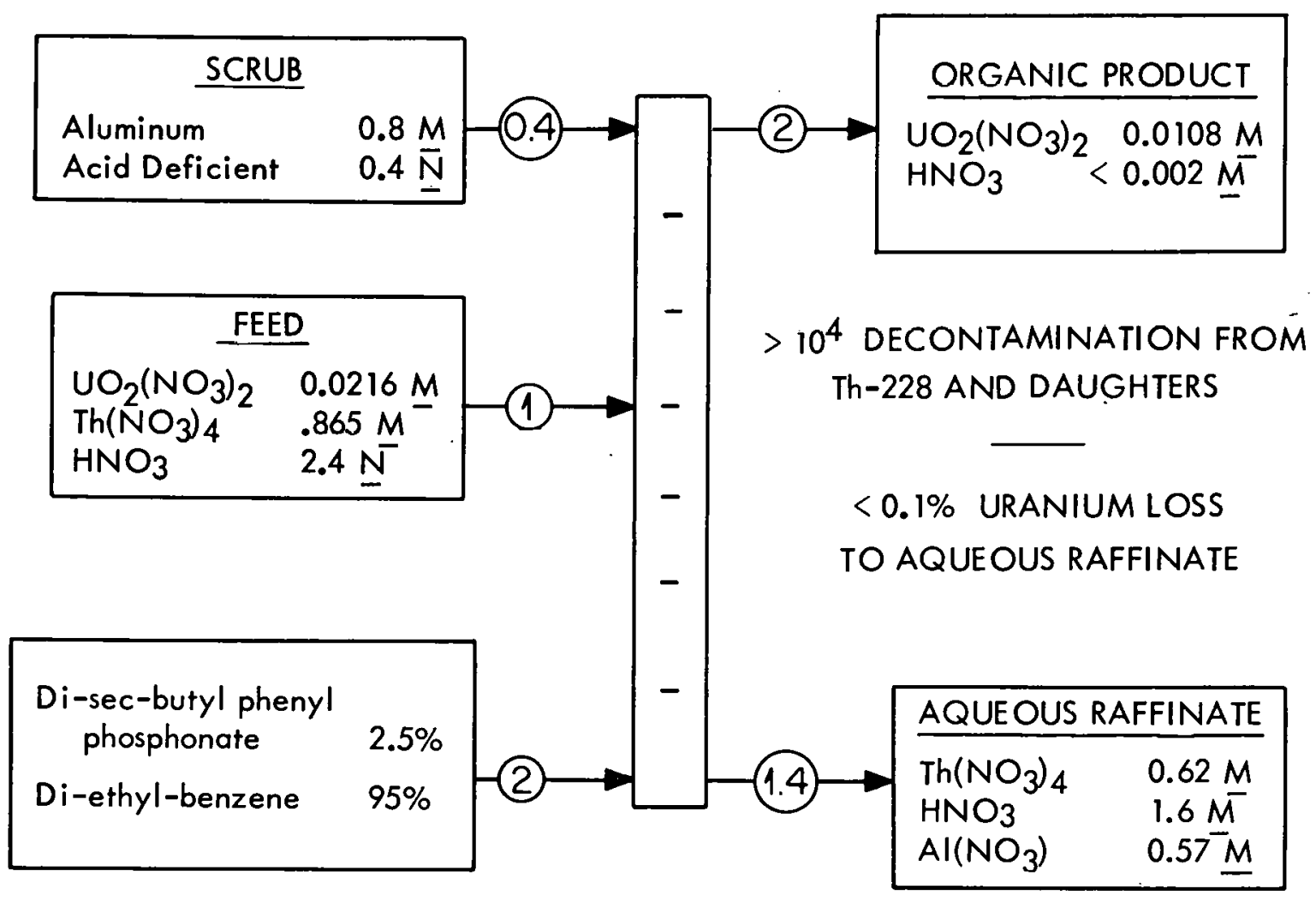

Fig. 20. Kilorod Interim-23 process. 
higher by a factor of 4 in the DSBPP system at thorium concentrations less than $100 \mathrm{~g} /$ liter. $44,45,46$ The increase in separation occurs principally in the scrub section of the column. The acid deficient aluminum nitrate scrub produces a low acidity product, with a nitrate-to-uranium ratio of 2.18 as required by the Sol-Gel fuel preparation process which follows in the Kilorod Program. Decontamination from $\mathrm{Th}^{228}$ and its' daughters is approximately $10^{4}$. Since DSBPP is not soluble in dodecane, an aromatic diluent, diethylbenzene (DEB) is used. The DSBPP in DEB is not as stable to chemical degradation as TBP in $n$-dodecane. When DSBPP in DEB was stirred 16 hil with nonradioactive feed and then issed in a laboratory experiment, the distribution coefficient of uranium in the scrub section decreased by a factor of about 2. Decontamination from $\mathrm{Th}^{228}$, however, was unalfected.

This separation of uranium from the daughters of $U^{232}$ provides a product which can be handled in the semiremote, Sol-Gel vibratory-compaction equipment for at least ten days without overexposure to workers. The growth of activity in the product (Fig. 21) duplicates that predicted for the growth of the daughters of $U^{232}$ in the natural activity of the $U^{233} .47$

\subsection{Protactinium Recovery Systems}

The presence of relatively long half-life (27 days) $\mathrm{Pa}^{233}$ in short-decayed thorium reactor fuel, constitutes a major difficulty in the reprocessing of such fuel. Immediately after discharge from the reactor the protactinium is responsible for 90 to $99 \%$ of the beta-gamma activity and as much as $10 \%$ of the potential $U^{233}$ in the fuel. With either the Interim 23 or the Acid Thorex flowsheet, the protactinium is hydrolyzed or precipitated in the acid feed solution and is not extracted with the solvent. Two processes being studied in the laboratory for possible recovery of the protactinium from short-decayed thorium fuel solutions are: (1) adsorption of protactinium from highly acidic dissolver solution on silica gel or on unfired powdered Vycor glass or (2) the coextraction of the protactinium with the thorium and uranium, using a Thorextype solvent extraction flowsheet.

Solubility studies on $\mathrm{Pa}^{231}$ showed that protactinium remained homogeneously dispersed in solutions equivalent to those to be obtained in dissolution and feed of 


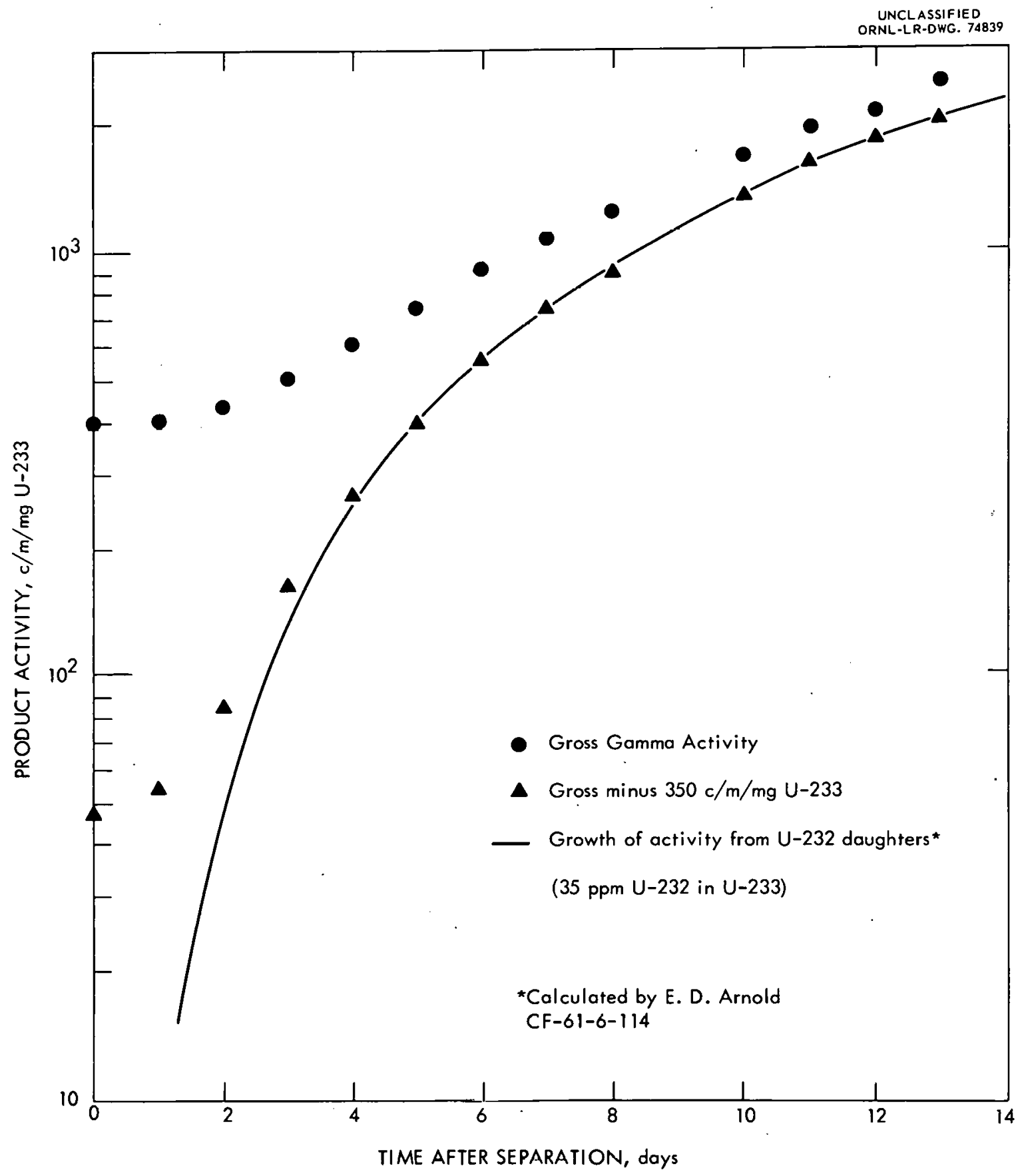

Fig. 21. Growth of activity in U-233 following solvent extraction purification. 
Consolidated Edison fuel irradiated to 20,000 Mwd/ton. The solutions contained $116 \mathrm{~g} /$ liter Th, approximately $0.07 \mathrm{~g} /$ liter $\mathrm{Pa}, 11 \mathrm{M} \mathrm{HNO}_{3}, 0.1 \mathrm{M} \mathrm{Al}$, less than 0.1

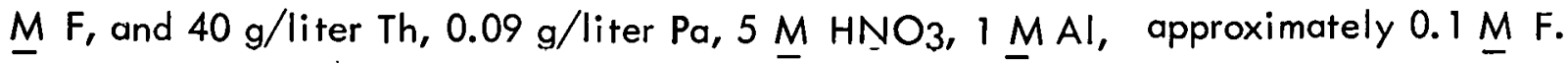
Such solutions showed no decrease in protactinium concentration after standing in a plastic container for a month at room temperature. These solutions also showed no change in concentration after contacting either welded or unwelded type 347 stainless steel coupons for one week at room temperature. 48 The solubilities are in agreement with the observations of Hardy et al. 49 that protactinium stock solutions containing $10^{-3} \mathrm{M} \mathrm{Pu}$ in $6 \mathrm{NJ}^{1} \mathrm{INNO}_{3}$ were stablc for many months.

Laboratory experiments demonstrated that at least $95 \%$ of the protactinium in the synthetic dissolver solution could be adsorbed on columns containing either unfired Vycor glass or laboratory-prepared silica gel. 48 When the experiments were terminated, the columns contained 5.0 and $3.2 \mathrm{mg}$ of protactinium per gram of adsorbent, respectively. The amount of protactinium not adsorbed remained constant throughout the experiment. The protactinium was eluted at six times the feed concentration with $0.5 \mathrm{M}$ oxalic acid. These laboratory experiments indicate that the protactinium in short-decayed thorium fuel may be adsorbed on radiation-stable inorganic materials directly from the dissolver solution. The decrease in activity of the thorium-uranium solution due to $95 \%$ removal of protactinium is equivalent to about a four-month decay of the fuel.

A low-decontamination "Acid Co-Extraction Process" is also being developed 50 for the recovery of protactinium in which protactinium, uranium, and thorium are simultaneously extracted from highly acid feed solutions with $30 \%$ TBP. In experiments with tracer protactinium, about $90 \%$ of it was extracted from $5 \mathrm{M} \mathrm{HNO}_{3}^{--}$ $1 \mathrm{M} \mathrm{Al}\left(\mathrm{NO}_{3}\right)_{3}$, resulting in a decontamination factor of 70 from ruthenium and about $10^{\overline{5}}$ from rare earths. About half of the zirconium-niobium extracts with the product. A partitioning strip or a second solvent extraction cycle could be used to separate protactinium from uranium and thorium and to increase decontamination from fission products. Much of the zirconium-niobium will accompany the protactinium in this system, but additional decontamination is obtained by the decay of 65-day half-life $\mathrm{Zr}^{95}$ during the decay of the 27-day half-life $\mathrm{Pa}^{233}$. 
Either of these short decay processes results in the separation of protactinium, which will decay to $U^{233}$ almost free of $U^{232}$. Such $U^{233}$ is valuable for special uses.

\section{CHOICE OF REPROCESSING METHOD}

\subsection{Thorium Fuel Processes}

The choice of a processing method for the recovery of irradiated thorium fuels depends on which of the following objectives must be met: (1) short cooling times with immediate co-recovery of $U^{233}$, thorium, and protactinium vs long cooling for complete decay of $\mathrm{Pa}^{233}$ to $U^{233}$ before recovery of $U^{233}$ and thorium; or (2) short cooling time and recovery of $U^{233}$ alone in a first cycle followed at a later time by recovery of additional $U^{233}$ (and thorium, if desired) after complete decay of $\mathrm{Pa}^{233}$. These considerations do not particularly affect the choice of fuel decladding or dissolution methods but seriously affect the choice of solvent extraction method. Items to be considered are: (1) solubility of protactinium in nitrate systems, (2) separation chemistry of protactinium in systems containing macro amounts of protactinium, (3) relative processing rates, and (4) volume of radioactive wastes. A summary of the extraction system variables taken from Figures 18 and 19 is given in Table 7.

The objective of recent solvent extraction development work has been to define these variables and thus obtain the data necessary for the choice of a processing method based on economics rather than chemical engineering limitations. For example, at present, short-cooled processes for direct extraction of $\mathrm{Pa}^{233}$ from nitrate systems could nut be operated with guaranteed success since most development work on Pa233 recovery from nitrate solution has been done on a tracer scale. Experiments with macro amounts of $\mathrm{Pa}^{231}$ are in progress to confirm promising tracer-scale results. The solubility of protactinium appears to be sufficiently high in nitric acid Thorex dissolver solutions to warrant consideration of direct processing. At least $90 \%$ of the protactinium can be adsorbed directly from this solution on unfired $V y c o r$ or on silica gel. Thus the Acid Thorex process could be used for direct recovery of $U^{233}$ and thorium in short-cooled processing after protactinium adsorption or after complete decay of $\mathrm{Pa}^{233}$ 
Table 7. Choice of Acid Extraction Process

\begin{tabular}{lclcc}
\hline \multicolumn{1}{c}{ Process } & $\begin{array}{c}\text { Cooling } \\
\text { (days) }\end{array}$ & \multicolumn{1}{c}{$\begin{array}{c}\text { No. } \\
\text { Cycles }\end{array}$} & $\begin{array}{c}\text { Rate } \\
\text { (tonnes Th/day) }\end{array}$ & $\begin{array}{c}\text { Waste Vol. } \\
\text { (gal/tonne Th) }\end{array}$ \\
\hline Interim 23 & $<90$ & $2, U$ & 0.5 & 530 \\
& $>120$ & $1, U$ & 1 & 530 \\
Thorex & $>120$ & $1, U$ and Th & 0.5 & 53 \\
Co-Ext. Thorex & $<90$ & $\begin{array}{l}1, U \\
\text { Pa and Th }\end{array}$ & 0.2 & $\sim 60$ \\
\hline
\end{tabular}

For AEC conceptual plant; not applicable to plant optimized for thorium and uranium recycle processing.

but is not suitable for co-extraction of uranium, protactinium, and thorium since the protactinium is hydrolyzed in the acid-deficient feed. However, the low-decontamination Acid Co-Extraction process can probably be used to recover uranium, thorium, and protactinium simultaneously. The low decontamination factors for zirconium and niobium obtained in this process may not be significant since zirconium and niobium have low cross sections, and remote fuel fabrication is required in any event. The high-cross-section fission products are removed by factors of about $10^{4}$ (see Sec 4.4).

The Interim 23 process, where only $U^{233}$ is recovered, has a significant advantage over the Acid Thorex process in terms of maximum processing rate in a given set of critically safe equipment. With $5 \%$ TBP solvent, the thorium processing rate is 2 to 3 times that of the Acid Thorex process. But if the solvent concentration is limited to $2.5 \%$, as is customary for criticality control, the processing rates are about the same.

The Acid Thorex process, where both uranium and thorium are recovered, has a distinct advantage over the Interim 23 process in terms of volume of high-level waste. Since the thorium remains in the aqueous raffinate with the fission products in the Interim 23 system, the evaporated waste volume is 10 times greater than for the Acid Thorex process.

Obviously, a final choice between the Interim 23 and Acid Thorex processes will depend on many variables. So long as thorium reactors are fueled with $U^{235}$ and fresh 
(unirradiated) thorium or $U^{235}$ containing small amounts of recycled $U^{233}$ and $U^{232}$ and fresh thorium, direct fuel fabrication with minimal shielding is possible. In this case, the Interim 23 process will probably be preferable because of its potential quick recovery of $\mathrm{U}^{233}$ for short cooling times, and hence, low fuel amortization costs. However, when reactors are fueled with $\mathrm{U}^{233}$, complete remote fuel fabrication will be required with either fresh or recycled thorium, and the Acid Thorex or Acid CoExtraction processes may be preferable. Calculations by E. D. Arnold show that the specific activity of infinitely recycled thorium and infinitely recycled uranium will be approximately equal and hence that the shielding required for fabrication of $U^{233}$ thorium fuels will be increased by only $20 \%$ if recycled thorium is used. A complete re-evaluation of fuel cycle economics will be required when $U^{233}$ fuels are to be fabricated and the additional results are available from the new technology now under development.

\subsection{Processing Costs}

A brief survey of the costs of recovery processes for irradiated thorium-uranium fuel was made with the assistance of A. D. Ryon, E. L. Nicholson, J. O. Blomeke and J. J. Perona (Table 8). For comparison purposes Acid Interim-23 (Fig. 18) and Acid Thorex (Fig. 19) flowsheets were drawn which use the same feed solution and represent nearly maximum throughput. The total volumetric capacities of the extraction columns were estimated by A. D. Ryon as 900 and $600 \mathrm{~g} / \mathrm{hr} \mathrm{ft}^{2}$ for the Acid Thorex and Acid Interim-23 flowsheets, respectively. This indicates Acid Interim 23 thorium capacity for thorium extraction 2.03 times greater than Thorex for a given column size. An evaluation of thorium processing in the conceptual AEC multipurpose fuel processing plant by E. L. Nicholson indicated that the plant capacity would be governed by the solvent system and that the Interim 23 process would have a capacity twice that for Thorex and that the difference in the cost of the fuel processing is not significant (Table 8). However, in this case the system is optimized for uranium recovery with the Purex process. A comparison of two plants with equal thorium processing capacity and optimized for the Acid Thorex or Acid Interim 23 processes showed an insignificant increase in capital and operating costs for the Acid Thorex process. The increase results 
Table 8. Comparative Overall Cost of Acid Interim 23 and Thorex Processes in the AEC Conceptual Plant 51

Either process will recover $\mathrm{U}^{233}$, which, based on $5 \%$ fuel, will be valued at $\$ 750,000$ (50 kg $U^{233}$ at $\$ 15$ per gram in each tonne of thorium)

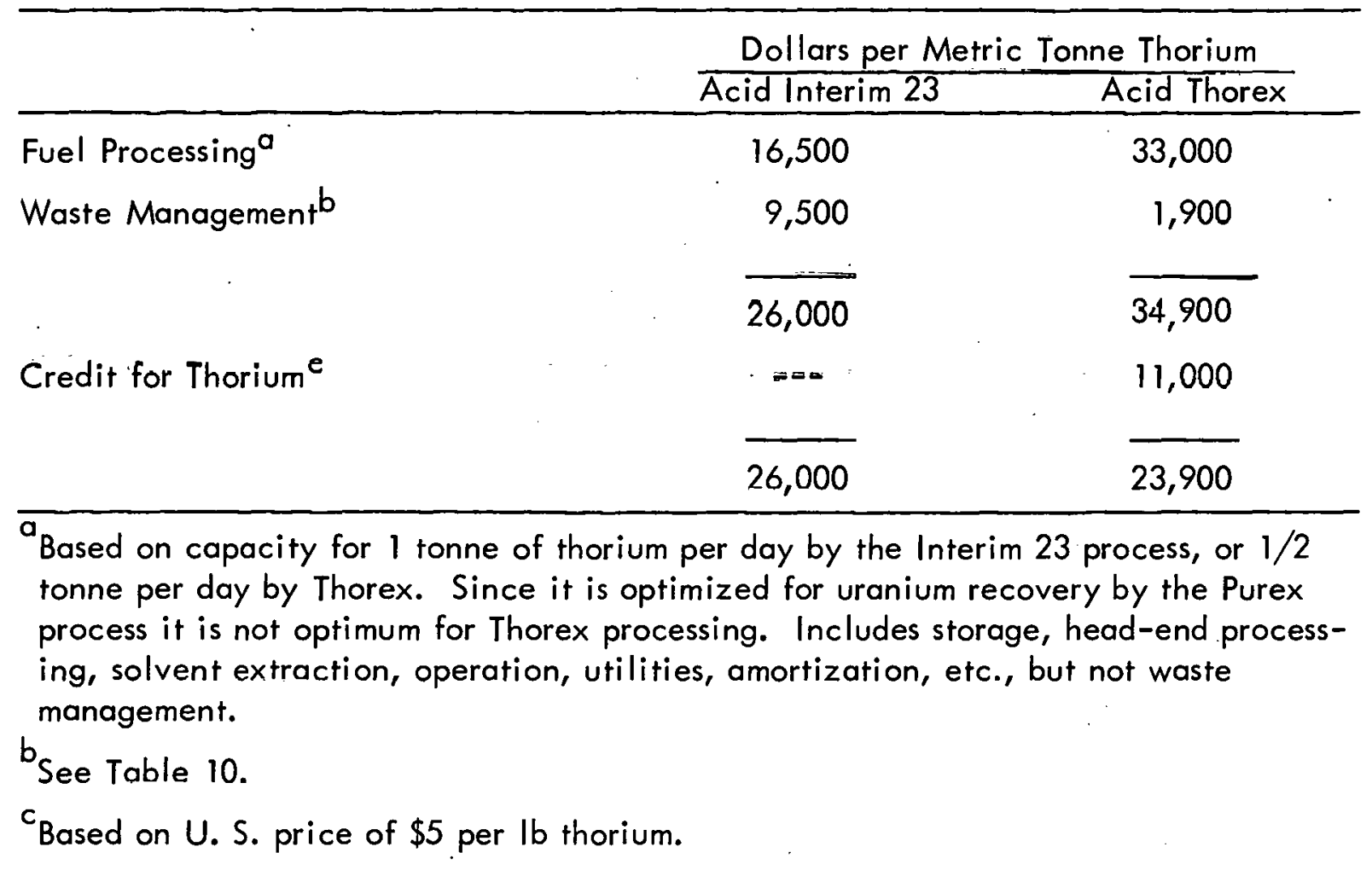

from amortization of larger solvent equipment required for the Acid Thorex process. Previous estimates 51 have shown that the total cost of extraction equipment is only about $12 \%$ of the cost of the complete plant. Under these conditions the Thorex plant results in a much lower fuel processing cost (Table 9).

Estimates by J. O. Blomeke and J. J. Perona for management of the high-level wastes from Interim 23 and acidic Thorex processing were based on previous cost studies made for Purex and Thorex wastes 52 (Table 10). Interim 23 processing is assumed in the first case with thorium remaining in the waste through final disposal. In the second case, recovery of thorium from Acid Interim 23 raffinate after 12 years of storage is assumed. Cost of the reprocessing of the solution for thorium recovery is not included. 
The value of the thorium is assumed to pay for its recovery cost. The third case is for Acid Thorex. The raffinate volumes and compositions given in Figs. 18 and 19 were used as a basis for comparison. In all cases, the wastes were assumed to be evaporated, stored 12 years as liquids, converted to solids by pot calcination, stored for 18 years as solids in water-filled canals, shipped 1000 miles to a salt mine, and finally, disposed of permanently by burial in salt mines.

Both acid flowsheets being compared are at about the same level of development; they have resulted in excellent operation in laboratory equipment using tracer solutions but have not been evaluated at full-activity levels or in engineering equipment. Neither is sufficiently different from previously demonstrated processes (other than the chemistry of protactinium) that major operational difficulties would be expected.

Table 9. Comparative Overall Cost of Acid Interim 23 and Thorex Processes in Equipment Designed for Optimized Flowsheets ${ }^{a}$

\begin{tabular}{lcc}
\hline & \multicolumn{2}{c}{ Dollars per Metric Tonne Thorium } \\
\cline { 2 - 3 } Fuel Processing & Acid Interim 23 & Acid Thorex \\
Waste Management & $\frac{9,500}{16,500}$ & $\frac{1,900}{20,400}$ \\
Credit for Thorium & $\frac{26,000}{-}$ & 11,000 \\
\hline
\end{tabular}

${ }^{a}$ Same basis as for Table 8 .

b Allowances for solvent extraction equipment ( $12 \%$ of total charges) have been doubled to give a generous allowance for plant modifications. 
Table 10. Waste Management Costs for Interim 23 and Acid Thorex Processes

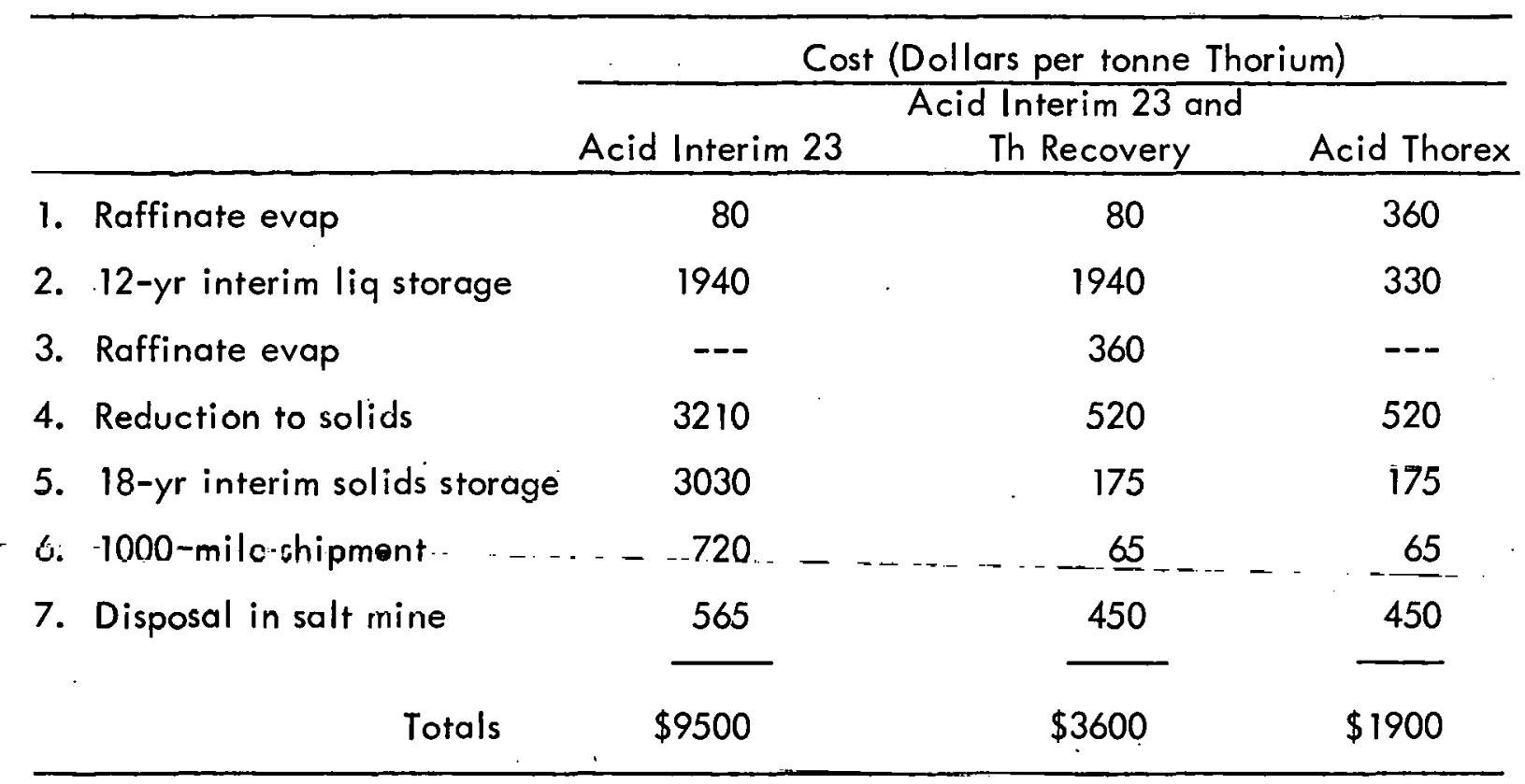

\section{REFERENCES}

1. R. E. Blanco, L. M. Ferris, D. E. Ferguson, Aqueous Processing of Thorium Fuels, ORNL-3219 (Feb. 28, 1962). (Part 1).

2. C. D. Watson, et al., "Performance of Mechanical Equipment for Dejacketing Spent SRE I Fuel," to be included in the Proceedings of the 10th Hot Laboratory and Equipment Conference, American Nuclear Society Meeting, November 26, 27, 28, 1962, Washington, D. C. (August 1962).

3. J. P. Simon and J. R. White, "Mechanical Decanning of EBR II Fuel Elements," Proceedings of the Tenth Conference on Hot Laboratories and Equipment, Washington, D. C., November 26-29, 1962, The American Nuclear Society, Chicago, Illinois.

4. J. P. Simon and R. B. Wehrle, "EBR II Fuel Dismantling Equipment," Proceedings of the Tenth Conference on Hot Laboratories and Equipment, Washington, D. C., Nov. 26-29, 1962, The American Nuclear Society, Chicago, Illinois. 
5. T. C. Runion, NFS Chemical Processing Plant - Capability and Cost Study, Davison Chemical Company, pp 9, 12 (May 1962).

6. KLX 1840, Conceptual Study Chop Leach Demonstration Facility for Phillips Petroleum Company, Vitro Engineering Company, N. Y. 7, N. Y. (June 1962).

7. J. B. Adams et al., Comparative Cost Study of Processing Stainless Steel Jacketed $\mathrm{UO}_{2}$ Fuel; Mechanical Shear-Leach vs Sulfex-Core Dissolution, ORNL-3227 (Aprii 1962).

8. R. L. Ashley et al., SRE Fuel Element Damage Final Report, NAA-SR-4488 (Suppl), pp IV-9, 11, 12 (June 30, 1961).

9. J. B. Adams, A Survey of the Hazards Involved in Processing Liquid Metal Bonded Fuels, ORNL-3147 (July 31, 1961).

10. R. L. Ashley, SRE Fuel Element Damage Final Report, NAA 4488 (Nov. 30, 1959).

11. D. I. Sinizer, et al., Irradiation Behavior of Uranium Carbide Fuels, NAA-SR-7248, pp 28-29 (August 1962).

12. Chemical Technology Division Unit Operations Section Monthly Progress Report, October 1962, ORNL-TM-412.

13. Chemical Development Section B Quarterly Progress Report for July-September 1962, ORNL-TM-403 (Feb. 7, 1963).

14. M. E. Whatley, et al., Unit Operations Section Monthly Progress Report, January 1962, ORNL-T $\overline{M-150 .}$

15. Robert A. Ewing, et al., Sulfex-Thorex and Darex-Thorex Dissolution of HighBurnup Consolidated Edison Reactor Fuel, BMI-1560, pp 1, 13, 15, 23 (December 1961).

16. F. L. Culler, R. E. Blanco, L. M. Ferris, E. L. Nicholson, R. H. Rainey, J. W. Ullmann, Nucleonics, 20, 124 (1962).

17. L. M. Ferris and A. H. Kibbey, Sulfex-Thorex and Darex-Thorex Processes for the Dissolution of Consolidated Edison Power Reactor Fuel: Laboratory Development, ORNL-2934 (Oct. 26, 1960).

18. B. C. Finney and B. A. Hannaford, Sulfex Process: Engineering-Scale Semicontinuous Decladding of Unirradiated Stainless Steel-Clad $\mathrm{UO}_{2}$ and $\mathrm{UO}_{2}-\mathrm{ThO}_{2}$, ORNL-3072 (March 22, 1961). 
19. J. J. Shefcik, Darex Pilot Plant Studies, HW-62537 (Oct. 29, 1959).

20. F. D. Fisher, The Sulfex Process Terminal Development Report, HW-66439 (Aug. $22,1960)$.

21. F. G. Kitts and W. E. Clark, The Darex Process: The Treatment of Stainless Steel Reactor Fuels with Dilute Aqua Regia, ORNL-2712 (May 23, 1962).

22. R. A. Ewing, H. B. Brugger, and D. N. Sunderman, Dissolution of Irradiated Consolidated Edison Power Reactor Fuel by the Sulfex and Darex Processes, BMI-1427 (March 10, 1960).

23. L. M. Ferris and A. H. Kibbey, Miscellaneous Experiments Relating to the Processing of CETR Fuel by Sulfex-Thorex and Darex-Thorex Processes, ORNL-3143 (Aug, 16, 1961).

24. L. M. Ferris, Zirflex Process for PWR Blanket Fuel. II. Revised Flowsheet, ORNL-2940 (Nov. 9, 1960).

25. P. W. Smith, The Zirflex Process Terminal Development Report, HW-65979 (Aug. 20, 1960).

26. J. L. Swanson, "The Selective Dissolution of Zirconium or Zircaloy Cladding by the Zirflex Process," Proc. 2nd UN Internat'l Conf. Peaceful Uses Atomic Energy, Geneva, 1958, P/2429, Vol. 17, p 154.

27. L. M. Ferris, Process for Dissolution of BORAX-IV Reactor Fuel: Laboratory Development, ORNL-2821 (Jan. 18, 1960).

28. J. A. McBride, Idaho Chemical Processing Plant, personal communication (April 1962).

29. W. D. Bond, Dissolution of Sintered Thorium-Uranium Oxide Fuel in Nitric AcidFluoride Solutions, ORNL-2519 (Oct. 28, 1958).

30. M. J. Bradley and L. M. Ferris, Nucl. Sci. and Eng., 8, 432 (1960).

31. M. J. Bradley and L. M. Ferris, Ind. Eng. Chem., 53, 279 (1961).

32. L. M. Ferris, A. H. Kibbey, and M. J. Bradley, Processes for Recovery of Uranium and Thorium from Graphite-base Fuel Elements, Part II, ORNL-3186 (Nov. 16, 1961).

33. L. M. Ferris, Chemical Processing of Coated Particle Fuels, ORNL-TM-193 (April 3, 1962). 
34. M. J. Bradley and L. M. Ferris, Inorg. Chem., I, 683 (1962).

35. M. J. Bradley and L. M. Ferris, Processing of Uranium Carbide Fuels. 1. Reaction with Water and $\mathrm{HCl}$, ORNL-3101 (Aug. 1, 1961).

36. K. S. Warren, L. M. Ferris, A. H. Kibbey, Dissolution of $\mathrm{BeO}$ - and $\mathrm{Al}_{2} \mathrm{O}_{3}-\mathrm{Base}$ Reactor Fuel Elements. Part I, ORNL-3220 (Jan. 30, 1962).

37. R. H. Rainey and J. G. Moore, "Acid Interim 23 Process," in Chemical Technology Division Chemical Development Section B Monthly Progress Report September 1959, ORNL-CF-59-10-113, p 28.

38. R. H. Rainey and J. G. Moore, "Laboratory Development of the Acid Thorex Process for Recovery of Thorium Reactor Fuels," Nucl. Sci. and Eng., Vol. 10, No. 4, pp 367-371 (1961) and U. S. Patent 3,049,400.

39. A. T. Gresky, "Solvent Extraction Separation of U-233 and Thorium from Fission Products by Means of Tributyl Phosphate," Proc. Internat'l Conf. on Peaceful Uses of Atomic Energy, Vol. 9, p 505 (1956). A. T. Gresky, Progress Report Laboratory Development of the Thorex Process, ORNL-1367 (1952). Summarized in Reactor Handbook, Vol. II, Fuel Reprocessing, p 211.

40. A. D. Ryon, "Solvent Extraction Studies," in Chemical Technology Division Unit Operations Section Monthly Progress Report, ORNL-CF-60-10-49, p 33 (1960).

41. R. H. Rainey and J. G. Moore, Laboratory Development of the Acid Thorex Process for Recovery of Consolidated Edison Thorium Reactor Fuel, ORNL-3155.

42. R. H. Rainey, "Recovery of Uranium-233 for the Kilorod Program," in Chemical Technology Division, Chemical Development Section B, Summary Progress Report, ORNL-TM-377, p 25 (October 1962).

43. D. E. Ferguson, E. D. Arnold, W. S. Ernst, and O. C. Dean, Preparation and Fabrication of $\mathrm{ThO}_{2}$ Fuels, ORNL-3225 (1962).

44. A. T. Gresky and R. G. Mansfield, Comparison of Organic Extractants for Irradiated Uranium: Tributylphosphate vs Di-sec-butyl Phenylphosphonate, Di-n-butyl Phenylphosphonate, Tri-caprylphosphate and Tri-sec-butylphosphate, ORNLCF-59-6-15.

45. R. H. Rainey, "Extraction of Uranium and Thorium with Tributyl Phosphate or Disecbutyl Phenyl Phosphonate," in Chemical Technology Division Chemical Development Section B Summary Progress Report, ORNL-TM-377, p 28 (October 1962).

46. C.. A. Blake, A. T. Gresky, J., M. Schmitt, and R. G. Mansfield, Comparison of Dialkyl Phenyl Phosphonates with Tributyl Phosphate in Nitrate Systems, ORNL-3374 (January 1963). 
47. See paper this session, Radiation Hazards of Recycled U-233-Thorium Fuels, E. D. Arnold, Oak Ridge National Laboratory.

48. J. G. Moore, "Thorium-Protactinium Solutions," in Chemical Technology Division Chemical Development Section B, Summary Progress Report, ORNL-TM-403, p 24 (Feb. 7, 1963).

49. C. J. Hardy, D. Scargill, and J. M. Fletcher, "Studies on Protactinium(V) in Nitric Acid Solutions," J. Inorg. Nucl. Chem., Vol 7, p 257-275 (1958) and personal communication.

50. R. H. Rainey, "Coextraction of Uranium, Thorium and Protactinium," in Chemical Ter.hnology Division, Chemical Development Section B, Summary Progress Report, ORNL-TM-177, p 32 (May 1962).

51. Summary Report: AEC Reference Fuel Processing Plant, Division of Civilian Application, USAEC, WASH-743 (October 1957).

52. R. L. Bradshaw, J. J. Perona, J. T. Roberts, and J. O. Blomeke, a) Evaluation of Ultimate Disposal Methods for Liquid and Solid Radioactive Wastes: Part 1. Interim Liquid Storage, ORNL-3128 (August 1961). b) J. J. Perona; R. L. Bradshaw, J. T. Roberts, and J. O. Blomeke, Conversion to Solids by Pot Calcination, ORNL3192 (September 1961). c) J. J. Perona, R. L. Bradshaw, J. O. Blomeke, and J. T. Roberts, Shipment of Calcined Solids, ORNL-3356 (October 1962). d) Also additional unpublished data by the same authors. 
ORNL-3418

UC-10 - Chemical Separations Processes

for Plutonium and Uranium

TID-4500 (19th ed., Rev.)

\section{INTERNAL DISTRIBUTION}

1. Biology Library

2-3. Central Research Library

4. Reactor Division Library

5-6. ORNL - Y-12 Technical Library Document Reference Section

7-26. Laboratory Records Department

27. Laboratory Records, ORNL R.C.

28. L. G. Alexander

29. H. F. Bauman

30. R. E. Biggers

31. R. E. Blanco

32. J. O. Blomeke

33. J. C. Bresee

34. R. E. Brooksbank

35. K. B. Brown

36. W. L. Carter

37. F. L. Culler

38. F. W. Davis

39. D. A. Douglas, Jr.

40. J. L. English

41. D. E. Ferguson

42. L. M. Ferris

43. B. C. Finney

44. J. R. Flanary

45. H. E. Goeller

46. J. P. Hammond

47. T. G. Harmon
48. A. R. Irvine

49. G. W. Keilholtz

50. F. G. Kitts

51. C. E. Lamb

52. J. A. Lane

53. C. E. Larson

54. A. L. Lotts

55. W. D. Manly

56. E. C. Miller

57. E. C. Moncrief

58. E. L. Nicholson

59. A. M. Perry

60. S. A. Rabin

61. R. H. Rainey

62. A. D. Ryon

63. M. J. Skinner

64. J. A. Swartout

65. W. C. Thurber

66. J. W. Ullmann

67. C. D. Watson

68. A. M. Weinberg

69. M. E. Whatley

70. H. B. Whetsel

71. J. J. Katz (consultant)

72. T. H. Pigford (consultant)

73. C. E. Winters (consultant)

74. H. Worthington (consultant)

\section{EXTERNAL DISTRIBUTION}

75. E. L. Anderson, Atomic Energy Commission, Washington

76. R. F. Bcnenati, General Atomics

77. S. Bernstein, Union Carbide Nuclear Company, Paducah

78. J. A. Buckham, Idaho Chemical Processing Plant

79. J. T. Christy, Atomic Energy Commission, Hanford

80. F. R. Dowling, Atomic Energy Commission, Washington

81. M. K. Harmon, Hanford

82. L. P. Hatch, Brookhaven National Lahoratory 
83. O. F. Hill, Hanford

84. S. Lawroski, Argonne National Laboratory

85. J. A. McBride, Idaho Chemical Processing Plant

86. R. A. McGuire, Idaho Chemical Processing Plant

87. B. Manowitz, Brookhaven National Laboratory

88. J. W. Morris, du Pont, Savannah River Laboratory

89. W. H. Reas, Hanford

90. Kenneth Rohde, Idaho Chemical Processing Plant

91. C. A. Rohrman, Hanford

92. C. M. Slansky, Idaho Chemical Processing Plant

93. C. E. Stevenson, Argonne National Laboratory, Idaho

94. K. G. Steyer, General Atomics

95. V. R. Thayer, du Pont, Wilmington

96. R. E. Tomlinson, Hantord

97. W. Winsche, Brookhaven National Laboratory

98. Research and Development Division, AEC, ORO

99-590. Given distribution as shown in TID-4500 (19th ed., Rev.) under Chemical Separations Processes for Plutonium and Uranium category (75 copies - OTS) 